\title{
膀胱癌に対する膀腅部分切除術の臨床的 ならびに病理組織学的研究
}

\section{第 2 報＼cjkstart病理組織学的検索よりみた切除範囲の検討}

\author{
東北大学医学部泌原器科学教室
(主任: 浦宾仙太郎教授) \\ CLINICAL AND PATHOLOGICAL STUDIES ON PARTIAL CYSTECTOMY \\ FOR URINARY BLADDER CANCER \\ II. EXAMINATION ON THE REASONABLE EXTENSION OF VESICAL \\ WALL RESECTION WITH PATHOLOGICAL PROCEDURE \\ Tadao Miura \\ From the Department of Urology, School of Medicine, Tohoku University, Sendai
}

(Director: Prof. S. Shishito)

To clarify the reasonable extent of partial cystectomy, 48 specimens of vesical tumors obtained by partial cystectomy, and 25 specimens by total cystectomy were examined on the cell type and its infiltration sight as well as the histological aspect of vesical wall around the tumor, such as submucosal invasion, papillary hyperplasia, and Brunn's nest formation. And the following results were obtained.

1) The transitional cell type was most frequent in its incidence, more than 80 per cent, while the squamous and the undifferentiated cell type were less frequent in both the cases of partial and total cystectomy. Only one case of adenomatous cell type was found in the former case. As to the histological stage, the incidence of stage $A, B_{1}, B_{2}$, and $C$ were $50.0,29.2,12.5$, and 8.3 per cent in the partially cystectomized cases. While in the case of total cystectomy, they were 28.0, 12.0, 24.0, and 36.0 per cent respectively. In the cases of recurrence of tumor, the transitional cell type was found in 60.0 per cent, and the squamous and the undifferentiated cell type were also seen in 30.0 , and 10.0 per cent. As to the histological stage of these cases, the incidence of stage $\mathrm{A}, \mathrm{B}_{1}$, and $\mathrm{C}$ were $30.0,50.0$, and 20.0 per cent respectively.

2) In the specimens obtained by partial cystectomy, the submucosal invason of the tumor cell was found in 43.7 per cent at the part $1 \mathrm{~cm}$ from the tumor, while it was seen in 18.7 per cent at the part $2 \mathrm{~cm}$ from the tumor. The papillary hyperplasia was found in 50.0 per cent in the former part, while 18.7 per cent in the latter part, and there could be found significant difference between their incidence relating to the distance from the tumor. However, the Brunn's nest formation was found in 45.8 per cent and 34.4 per cent respectively, and there could not be found any marked difference in their incidence. On the other hand, the same examination was performed on the specimens obtained by total cystectomy, but almost the same results were obtained.

With these results described above, as well as the sight of subumucosal invasion and papillary hyperplasia which are thought to have rather close relationship with the recurrence of the tumor, it should be pointed out that the resection of enough margin of the vesical wall around the tumor, more than $2 \mathrm{~cm}$ should be desired, would be necessary for the partial cystectomy.

3) In the case of partial cystectomy, the incidence of submucosal invasion at the part $1 \mathrm{~cm}$ from the tumor was 25.0 per cent in stage A group, and 61.1-66.6 per cent in stage over $B_{1}$, while it was 41.6

* 研究生 
per cent at the part $2 \mathrm{~cm}$ from the tumor of stage $\mathrm{B}_{1}$. In the case of total cystectomy, it was $66.6-83.3$ per cent at the part $1 \mathrm{~cm}$ from the tumor of stage over $B_{1}$, while 77.7-83.3 per cent at the part $2 \mathrm{~cm}$ from the tumor of stage over $B_{2}$, and $25.0-50.0$ per cent at the part $3 \mathrm{~cm}$ from the tumor of stage over $B_{2}$.

With these results obtained above, it was clarified that the stage of the tumor was paralleled with the sight of submucosal invasion, however, any correlationship between the sight of invasion and the papillary hyperplasia or Brunn's nest formation could not be found. Therefore, it was assumed that the preoperative estimation upon the stage of the tumor would be very important to increase the clinical value of partial cystectomy for the bladder tumor, as well as the extension of the resection area if the stage might be rather high.

4) Further histological examinations on the sight or submucosal invasion around the tumor were made according to Jewett's classification, but symbols such as $a, b_{1}, b_{2}$, and c were employed not to be confused with the histological stage of the tumor described above. And the following results were obtained. In the case of partial cystectomy, submuccsal invasion of stage a was found in 71.4 per cent, stage $b_{1}$ in 23.8 per cent and stage $c$ in 4.8 per cent at the part $1 \mathrm{~cm}$ from the tumor, while invasion of stage a was found in 66.7 per cent, and stage $b_{1}$ in 33.3 per cent at the part $2 \mathrm{~cm}$ from the tumor, respectively. In the case of total cystectomy, stage $a$ in 70.7 per cent, stage $b_{1}$ in 23.5 per cent, and stage $c$ in 5.8 per cent were found at the part $1 \mathrm{~cm}$ from the tumor, while stage a in 92.3 per cent and stage c in 7.7 per cent were found at the part $2 \mathrm{~cm}$ from the tumor, and furthermore stage a in 83.3 per cent and stage $\mathrm{c}$ in 16.7 per cent were found at the part $3 \mathrm{~cm}$ from the tumor, respectively.

These results revealed that the submucosal invasion around the tumor would be extended into deeper part of the vesical wall in rather high incidence. Furthermore, it was significant that almost the same degree of submucosal invasion with the tumor, in 36.0 per cent at the part $1 \mathrm{~cm}$ from the tumor and in 40.0 per cent at the part $2 \mathrm{~cm}$ from the tumor was found even in the case with stage $b_{1}$ which was thought to be rather lower stage. Therefore, in the case of bladder tumor the extension of the submucosal invasion around the tumor should be assumed even in the early stage of its ocurrence. And it should be pointed out again that the resection of more than $2 \mathrm{~cm}$ margin of the vesical wall around the tumor should be necessary without any referrence of the stage of the tumor in partial cystectomy for the bladder tumor.

\section{第 1 章 緒 言}

膀胱部分切除術は，膀胱全摘除術とともに膀胱癌に対 して盛んに行われているが, Gammelgaard-Morville ${ }^{11}$ によれば $37.5 \%$ ， Masina ${ }^{2)}$ は34.8\%に再発が認められ たと述べまた Nichols-Marshall ${ }^{3}$ は 5 年以内に約 $50 \%$ ， さらに楠 ${ }^{4}$ は 3 年以内に $19 \%$ 再発のあるととを報告し ている．また教室でもすでに鈴木ら ${ }^{5)}$ が報告しているで とく, $27.3 \%$ に再発が認められている。すなわち, ある 程度の再発はまぬがれないととがわかるが，乙の原因に 関しては種々議論がなされ，現在までの意見としては， 腫瘍の浸潤度と切除範囲がもつとも関係があり,なかで も後者が重要であると考えられている。しかし実際に臨 床的に切除する場合の大きさとして, まず $\mathrm{Magri}^{6}{ }^{(1)}$ は 1 inch 以上, また Masina は少くとも $3 \mathrm{~cm}$ 巾に, さらに Baker $^{7}$ は膀胱の $1 / 3 \sim 2 / 3$ 切除するととを提唱している. すなわち，との切除範囲については未だ一定した規準が 定められていない.

よつて教室では，この点を明ら汃するとともに，膀
胱部分切除術の根治性の限界を知るために種々なる研究 を行つているが, 私はその一環として膀胱部分切除標本 および全摘除標本を用いて組織学的に切除範囲について 検索を行い， $2 ， 3$ の知見をえたのでこ〉に報告する.

\section{第 2 章 検索材料ならびに方法}

\section{第 1 節 検索材料}

昭和 34 年 4 月より昭和 40 年 1 月までの 5 年 10 力月間に 経験した原発性膀胱腫場のうち, 手術的にえられた全層 標本を検索材料とした。すなわち，膀胱部分切除例に関 しては48例を対象とし, 膀胱全摘除例では単発している 症例で, 肉眼的に周囲粘膜に浸潤の及んでいない25例の 標本を選び検索材料とした。

第 2 節 検索方法

1 腫瘍部に打ける検索

i 標本作成法

膀胱部分切除標本及び全摘除標本ともに, 図 1 のごと く腫瘍中心部ならびに腫瘍の両辺縁を含んだ部分で全層 標本を作成し，とれをパラフィンで包埋して，Hemato- 
図 1 腫瘍部における標本作成法

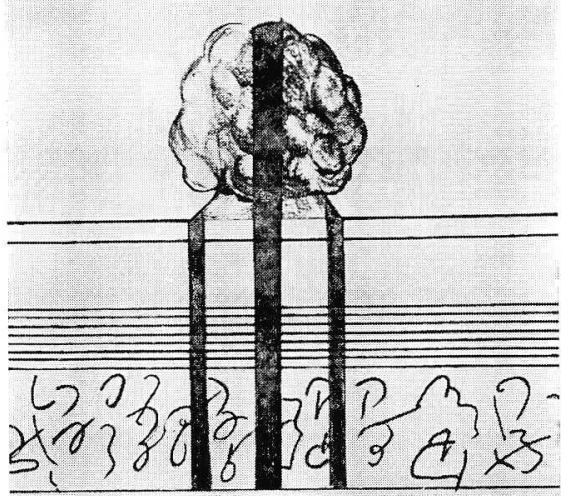

図 2 部分切除例に扣ける標本作成法

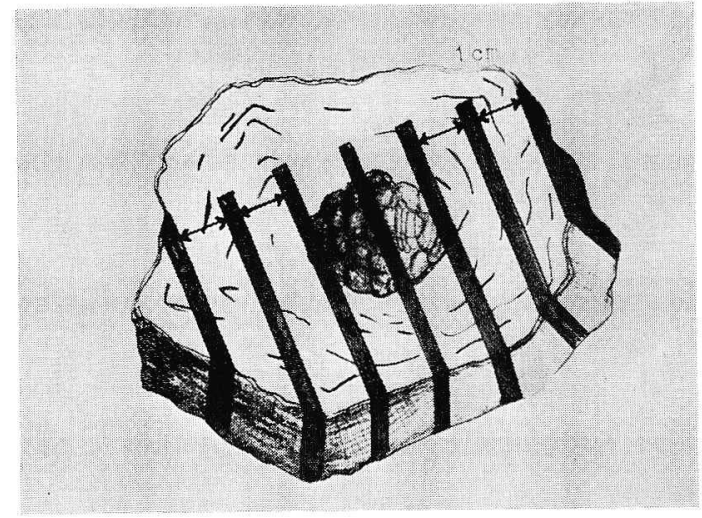

xylin Eosin 染色及ひ Van Gieson 染色を施行して標 本劣作成した。

\section{ii 検索方法}

細胞型，浸潤度について観察を行なつた。

a. 細胞型 : 膀胱腫瘁の主なる構成細胞の形態によつ て, 移行上皮型, 扁平上皮型, 未分化細胞型及び腺状細 胞型の 4 型に分類した.

b. 浸潤度 : 浸潤度は Jewett ${ }^{8)}$ の分類学基本とし， 表 1 の゙とく分類した.

2 腫瘍周囲における検索

\section{i 標本作成法}

膀胱部分切除標本及び全据除標本ともに腫瘍辺縁の肉 眼的に正常と思われる部位, すなわち腫瘍辺縁より両側 に向い，部分切除例では $1 \mathrm{~cm}$ 及び $2 \mathrm{~cm}$ 部位（図 2 ）, 全 摘除例では $1 \mathrm{~cm} ， 2 \mathrm{~cm}$ 及び $3 \mathrm{~cm}$ 部位（図 3 ）に抢ける 全層切片学作成した。これら組織切片をパラフィンで包 埋して, Hematoxylin Eosin 染色及び Van Gieson 染 色字施行して標本を作成した。
図 3 全摘除例における標本作成法

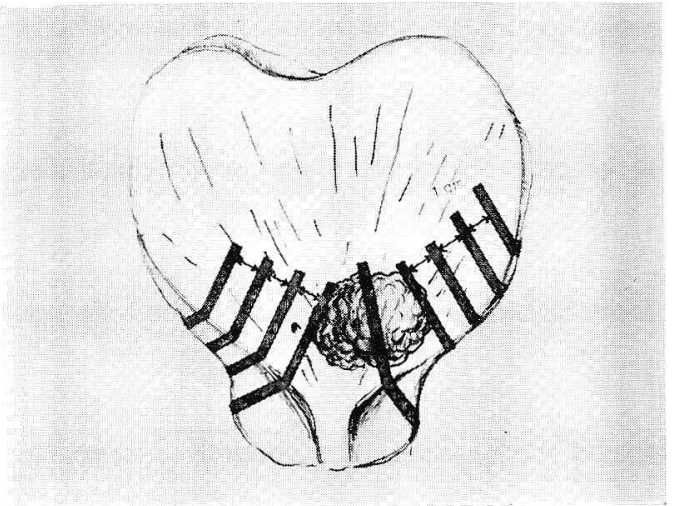

図 4 粘膜下浸潤像 $(10 \times 10, \mathrm{H}-\mathrm{E}$ 染色 $)$ 䧛胱部分切除標本の腫瘍辺縁より $1 \mathrm{~cm}$ の部位に扣け る組織像である。明らかに粘膜下に浸潤した所見で ある。

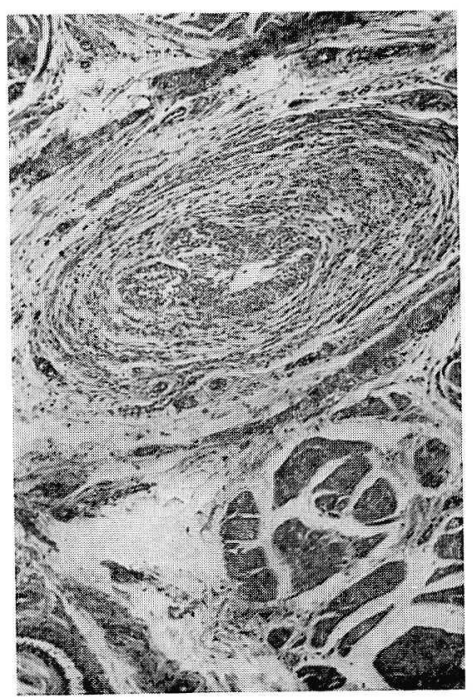

ii 観察規潐

腫瘍周囲においては, 粘膜下浸潤に重点を括いて検索 を行なつたが，乙の他粘膜の乳頭状增殖及び㓌窩形成の 有無についても詳細に観察し，1 カ所でもその変化が認 められた場合は陽性（十）とした。

a. 粘膜下浸潤 : 粘膜下浸潤の基準としては, 基底膜 の構造を失つて連続的に腫痬細胞が粘膜下に侵入してい るもの, また不連続的に粘膜下に腫痗細胞の浸潤を認め る場合を(十) とした（図 4 ).

b. 乳頭状増殖：浐胱上皮が重層化学来し，時には間 
図 5 乳頭状增殖像 $(6 \times 10, \mathrm{H}-\mathrm{E}$ 染色) 膀脱部分切除標本で腫瘍辺縁より $2 \mathrm{~cm}$ の部位に拈け る組織像である。粘膜下，箭層には浸潤を認めない が，粘膜は明らかに乳頭状增殖を示している。

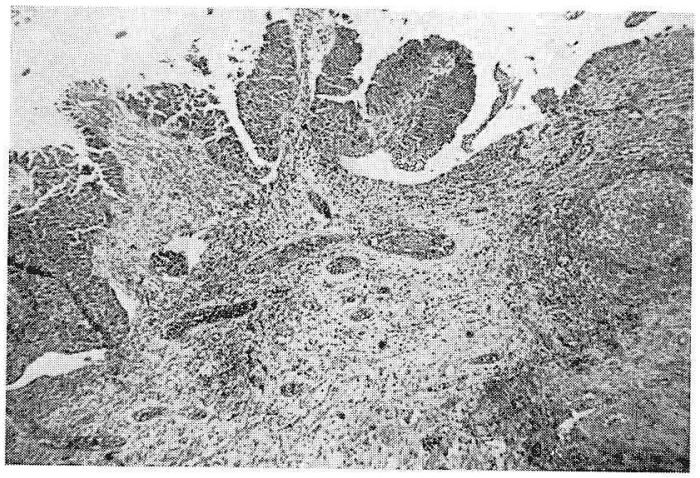

図 6 院窩形成像 $(10 \times 25, H-E$ 染色 $)$ 部分切除標本で腫瘍辺縁より $2 \mathrm{~cm}$ の部分に怙汀る組 織像である。粘膜は正常であるが一部に陰窩形成を 認める。

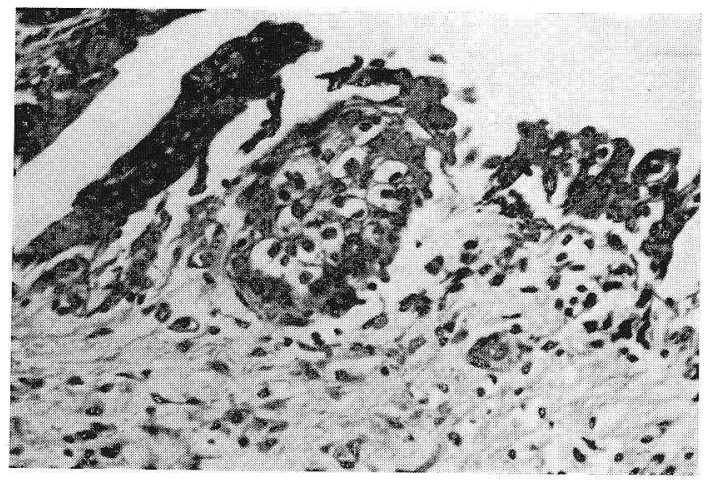

質を伴い，あるいは上皮の文か膀胱腔内に突出増殖を示 してはいるが，未だ腫瑒部の組織像をは明らかに異なる 所見を示式場合を乳頭状增殖と判定した（図５）.

c. 陰䆚形成 : 膀胱表層上皮との連絡が認められず， 腫瘍細胞とは明らかに異なる遊離性の上皮細胞巣，心わ ゆる Brunn の上皮細胞巣を形成しているものを（十） とした(図6).

\section{第 3 章 検索成績}

第 1 節 腫煌発生部位に打汀る検索結果

\section{1 細胞型}

i 膀胱部分切除例

膀胱部分切除例 48 例《怙ける成績定みると, 稳行上皮

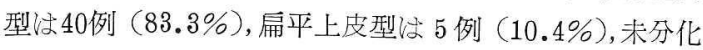

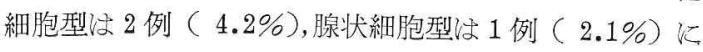

表 1 膀胼腫瘍における浸潤度の分類

\begin{tabular}{|c|c|c|c|c|}
\hline 浸潤度 & 浸 & 潤 & 状 & 態 \\
\hline $\mathrm{O}$ & \multicolumn{4}{|c|}{ 全く浸潤を欠く乳頭腫. } \\
\hline $\mathrm{A}$ & \multicolumn{4}{|c|}{ 粘膜下層までの浸潤の場合 } \\
\hline $\mathrm{B}_{1}$ & \multicolumn{4}{|c|}{ 筋層半ばまでの浸潤の場合 } \\
\hline $\mathrm{B}_{2}$ & \multicolumn{4}{|c|}{ 筋層半ばを越えて浸潤している場合 } \\
\hline $\mathrm{C}$ & \multicolumn{4}{|c|}{ 筋層を貫通して浸潤している場合 } \\
\hline
\end{tabular}

表 2 膀腅部分切除例における細胞型

\begin{tabular}{|c|c|c|c|c|c|}
\hline 細胞型 & $\begin{array}{l}\text { 移行上攴 } \\
\text { 型 }\end{array}$ & 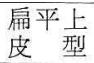 & $\begin{array}{l}\text { 未分化 } \\
\text { 細胞型 }\end{array}$ & $\begin{array}{l}\text { 腺 状細 } \\
\text { 型 }\end{array}$ & 計 \\
\hline 例 数 & 40 & 5 & 2 & 1 & 48 \\
\hline$\%$ & 83.3 & 10.4 & 4.2 & 2.1 & 100.0 \\
\hline
\end{tabular}

表 3 膀胱全摘除例に拈ける細胞型

\begin{tabular}{|c|c|c|c|c|}
\hline 細胞型 & 移行上皮型 & 扁平上皮型 & 未 分化細 胞型 & 計 \\
\hline 例数 & 22 & 2 & 1 & 25 \\
\hline$\%$ & 88.0 & 8.0 & 4.0 & 100.0 \\
\hline
\end{tabular}

認められた（表 2 ）。

ii 膀胱全摘除例

膀胱全摘除 25例の成績要及ると，移行上皮型泣22例 $(88.0 \%)$, 扁平上皮型议 2 例 $(8.0 \%)$, 未分化細胞型は 1 例 $(4.0 \%$ ) 示した（表 3 ).

2 浸潤度

i 膀胱部分切除例

浸潤度Oのものは1例も認められなかつたが，Aは24 例 $(50.0 \%), B_{1}$ 㹥14例 $(29.2 \%), B_{2}$ 核 6 例 $(12.5 \%)$, $\mathrm{C}$ 袮 4 例 $(8.3 \%)$ を示した（表4）.

ii 膀脱全摘除例

や注り浸潤度Oのものは認められなかつたが，Aは７ 例 $(28.0 \%), \mathrm{B}_{1}$ 江 3 例 $(12.0 \%), \mathrm{B}_{2}$ 注 6 例 $(24.0 \%)$ ， Cは 9 例 $(36.0 \%)$ を示した（表 5 ）.

表 4 膀胱部分切除例の浸潤度 (Jewett の分類)

\begin{tabular}{|c|c|c|c|}
\hline 浸潤度 & 例 & \multicolumn{2}{|c|}{$\%$} \\
\hline $\mathrm{O}$ & 0 & 0 & \multirow{3}{*}{79.2} \\
\hline $\bar{A}$ & 24 & 50.0 & \\
\hline $\mathrm{B}_{1}$ & 14 & 29.2 & \\
\hline $\mathrm{B}_{2}$ & 6 & 12.5 & \multirow{2}{*}{20.8} \\
\hline $\mathrm{C}$ & 4 & 8.3 & \\
\hline 計 & 48 & & \\
\hline
\end{tabular}


表 5 膀胱全摘除例の浸潤度 (Jewett の分類)

\begin{tabular}{|c|c|c|c|}
\hline 浸潤度 & 例 & \multicolumn{2}{|c|}{$\%$} \\
\hline $\mathrm{O}$ & 0 & 0 & \multirow{3}{*}{40.0} \\
\hline $\mathrm{A}$ & 7 & 28.0 & \\
\hline $\mathrm{B}_{1}$ & 3 & 12.0 & \\
\hline $\mathrm{B}_{2}$ & 6 & 24.0 & \multirow{2}{*}{$60: 0$} \\
\hline $\mathrm{C}$ & 9 & 36.0 & \\
\hline 計 & 25 & \multicolumn{2}{|c|}{100.0} \\
\hline
\end{tabular}

3 小括

まず細胞型についてみると，部分切除例と全摘除例と では別段差が認められず，いずれも移行上皮型がもつと も多く，80\%以上を占めている。ついで扁平上皮型が $8.0 \%$ 10.4\%,未分化細胞型が $2.1 \%$ 4.0\%を示し た。 この他部分切除例に执いて 1 例ではあるが腺状細胞 型が認められた。

つぎに浸潤度についてみると，Oのものは部分切除 例, 全摘除例ともに認められず, 部分切除例では浸潤度 $\mathrm{A}$ が50.0\%を示してもつとも多く, ついで $\mathrm{B}_{1}, \mathrm{~B}_{2}, \mathrm{C}$ の 順であるが，全摘除例では浸潤度 $\mathrm{C} の 36.0 \%$ 多もつとも 多く, ついで $\mathrm{A}, \mathrm{B}_{2}, \mathrm{~B}_{1}$ の順であり, 部分切除例と全摘 除例とではかなり異なっていた。 またての浸潤状態を筋
表 6 膀脳部分切除例の腫瘍縁より一定距 離に打ける变化

\begin{tabular}{|c|c|c|c|c|c|}
\hline \multirow{2}{*}{$\begin{array}{ll}\text { 症 } & \text { 例 } \\
\text { 番 } & \text { 号 }\end{array}$} & \multirow[b]{2}{*}{ 細 胞 型 } & \multirow[b]{2}{*}{ 浸潤度 } & \multicolumn{3}{|c|}{$1 \mathrm{~cm}$} \\
\hline & & & 粘膜 & 囎頭状 & $\begin{array}{l}\text { 䧔窩 } \\
\text { 形成 }\end{array}$ \\
\hline $27^{*}$ & 扁平上皮 & $\mathbf{B}_{1}$ & + & +1 & - \\
\hline $63^{*}$ & 移行上皮 & A & - & - & - \\
\hline $85 *$ & 扁平上皮 & A & - & - & - \\
\hline 164 & 移行上皮 & $\mathrm{A}$ & - & + & - \\
\hline 283 & 移行上皮 & $\mathrm{B}_{1}$ & + & + & - \\
\hline 317 & 移行上皮 & $\mathrm{B}_{2}$ & + & + & - \\
\hline $504 *$ & 扁平上皮 & $\mathrm{C}$ & + & - & 一 \\
\hline $617 *$ & 未分化 細胞 & $\mathrm{C}$ & + & + & + \\
\hline 896 & 腺状細胞 & $B_{1}$ & + & - & - \\
\hline 1559 & 移行上皮 & A & + & - & + \\
\hline $1718^{*}$ & 移行上皮 & A & - & + & + \\
\hline 1869 & 移行上皮 & $\mathrm{B}_{1}$ & - & + & - \\
\hline 1988 & 移行上皮 & $B_{1}$ & + & + & + \\
\hline 2015 & 移行上皮 & $\mathrm{B}_{2}$ & - & + & - \\
\hline 2819 & 移行上皮 & A & - & - & + \\
\hline 2847 & 移行上皮 & $\mathbf{B}_{1}$ & $t$ & + & + \\
\hline
\end{tabular}

層半ばまでのものと，筋層半ば以上との例にわけてみる と，部分切除例では浸潤が筋層半ばまでのものは79.2\%

表 7 膀胱部分切除例の腫瘍縁より一定距離における变化

\begin{tabular}{|c|c|c|c|c|c|c|c|c|c|c|c|c|c|c|c|c|c|}
\hline \multirow{2}{*}{$\begin{array}{ll}\text { 症 } & \text { 例 } \\
\text { 番 } & \text { 号 }\end{array}$} & \multirow[b]{2}{*}{ 細胞型 } & \multirow[b]{2}{*}{ 浸潤度 } & \multicolumn{3}{|c|}{$1 \quad \mathrm{~cm}$} & \multicolumn{3}{|c|}{$2 \mathrm{~cm}$} & \multirow{2}{*}{$\mid \begin{array}{ll}\text { 症 } & \text { 例 } \\
\text { 番 } & \text { 号 }\end{array}$} & \multirow[b]{2}{*}{ 細胞型 } & \multirow[b]{2}{*}{ 浸潤度 } & \multicolumn{3}{|c|}{$1 \mathrm{~cm}$} & \multicolumn{3}{|c|}{$2 \quad \mathrm{~cm}$} \\
\hline & & & $\begin{array}{l}\text { 粘膜 } \\
\text { 浸 } \\
\text { 潤 }\end{array}$ & 乳頭 & & $\begin{array}{l}\text { 粘膜 } \\
\text { 浸潤 }\end{array}$ & \begin{tabular}{|l|} 
乳頭: \\
块 \\
增殖 \\
\end{tabular} & & & & & \begin{tabular}{|l} 
粘膜 \\
浸潤
\end{tabular} & & & 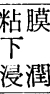 & $\begin{array}{l}\text { 乳頭 } \\
\text { 增殖 }\end{array}$ & 陰窩 \\
\hline 58 & 末分化細胞 & $\mathrm{C}$ & $1-$ & - & - & - & - & - & 2022 & 移行上皮 & $\mathrm{B}_{1}$ & + & + & + & + & + & + \\
\hline 342 & 移行上皮 & A & - & - & - & - & - & - & 2049 & 移行上皮 & A & + & - & - & - & - & - \\
\hline 476 & 移行上皮 & A & + & $t$ & + & - & + & + & 2073 & 移行上皮 & A & - & - & + & - & - & - \\
\hline 503 & 移行上皮 & $\mathrm{B}_{2}$ & + & + & - & - & - & - & 2095 & 移行上皮 & A & - & + & + & + & + & + \\
\hline 587 & 移行上皮 & $\mathrm{A}$ & - & + & + & - & + & + & 2167 & 移行上皮 & A & - & - & - & - & - & - \\
\hline 810 & 扁平上皮 & $\mathrm{B}_{1}$ & - & - & + & - & - & - & $2198 *$ & 移行上皮 & $\mathbf{B}_{1}$ & + & - & - & + & - & - \\
\hline 991 & 移行上皮 & $B_{1}$ & - & - & + & - & - & - & 2267 & 移行上皮 & A & - & + & - & - & + & - \\
\hline 1189 & 移行上皮 & A & - & + & - & - & - & - & 2287 & 扁平上皮 & A & + & + & + & - & - & - \\
\hline 1256 & 移行上皮 & A & - & + & + & - & - & - & 2305 & 移行上皮 & A & - & - & - & - & - & + \\
\hline 1387 & 移行上皮 & $\mathrm{A}$ & - & - & - & - & - & - & $2316 *$ & 移行上皮 & $\mathrm{B}_{1}$ & - & + & - & + & - & - \\
\hline 1492 & 移行上皮 & $\mathrm{B}_{1}$ & - & + & - & - & - & - & 2442 & 移行上皮 & $\mathrm{B}_{1}$ & + & - & - & + & - & - \\
\hline 1537 & 移行上皮 & $\mathrm{A}$ & + & - & + & - & - & + & 2449 & 移行上皮 & $B_{1}$ & - & - & + & - & - & + \\
\hline $1876^{*}$ & 移行上皮 & $\mathrm{B}_{1}$ & + & + & + & - & - & + & 2478 & 移行上皮 & $\mathrm{A}$ & + & - & - & - & - & + \\
\hline $1888^{*}$ & 移行上皮 & $B_{1}$ & + & + & + & - & - & + & 2678 & 移行上皮 & $\mathbf{B}_{1}$ & + & - & + & + & + & + \\
\hline 1897 & 移行上皮 & $\mathrm{A}$ & - & + & + & - & - & - & 2766 & 移行上皮 & $\mathrm{B}_{1}$ & - & - & - & - & - & - \\
\hline 2020 & 移行上皮 & A & - & - & - & - & - & - & 2778 & 移行上皮 & A & - & - & + & - & - & - \\
\hline
\end{tabular}

$*$ 再発例 
を占め，筋層を越えているものは $20.8 \%$ 示している が, 全摘除例では浸潤が筋層半ばまでの例は $40.0 \%$, 筋 層半ばを越えている例は $60.0 \%$ 示し, かなり差のある ととがわかる。

第 2 節 腫瘍周囲における病理組轼学的検索

1 腫痬縁より一定距離における变化

腫湟縁より $1 \mathrm{~cm}, 2 \mathrm{~cm}$ 及び $3 \mathrm{~cm}$ 部位に打ける粘膜下 浸潤, 乳頭状增殖及び陰窩形成の有無について検索し た.

\section{i 膀胱部分切除例}

部分切除例に执いては腫湯縁より $1 \mathrm{~cm}$ 及び $2 \mathrm{~cm}$ 部位 に打ける検索を全例に行いえなかつた.すなわち $1 \mathrm{~cm}$ 部位のみの検索にとでまつた症例は16例であり, $2 \mathrm{~cm} の$ 部位まで検索しえた症例は32例である（表 $6 ， 7$ ）。

まず, 検索が $1 \mathrm{~cm} の$ 部位のみにとどまつた症例につい てみると, 症例番号 (以下 No. と略稱する) 27では粘 膜下浸潤及び乳頭状增殖が認められたが，No. 63, 85で はいずれの変化も認められなかつた. No. 164では乳頭 状増殖の及認め, No. 283，317では粘膜下浸潤及び乳 頭状增殖を認めた．No．504では粘膜下浸潤のみを認 め, No. 617では粘膜下浸潤, 乳頭状增殖及び陰窩形成 がともに認められた. No. 896では粘膜下浸潤の及を認 め, No. 1559では粘膜下浸潤及び陰窩形成が認められ た. No. 1718では乳頭状増殖及び陰窩形成を認め, No. 1869 では乳頭状增殖のみの変化を示した. No. 1988では 粘膜下浸潤, 乳頭状增殖及び陰窩形成をともに認め, No. 2015では乳頭状增殖のみが認められた. No. 2819で は陰窩形成のみを認め, No. 2847では粘膜下浸潤, 乳頭 状増殖及び陰窩形成がともに認められた。

つぎに $2 \mathrm{~cm}$ 部位まで検索しえた症例についてみる と, No. $58,342 て ゙ は ~ 1 \mathrm{~cm}$ 及び $2 \mathrm{~cm}$ ともに変化が認めら

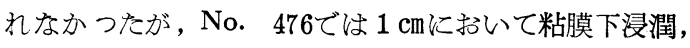

乳頭状增殖及び陰窩形成をともに認め, $2 \mathrm{~cm}$ 亿捻いては

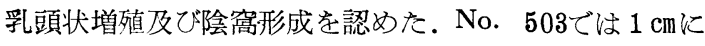
おいて粘膜下浸潤及び乳頭状增殖を認めたが， $2 \mathrm{~cm}$ に㧤 いてはいずれの変化も認められなかつた. No. 587では $1 \mathrm{~cm}$ 及び $2 \mathrm{~cm}$ ともに乳頭状増殖及び陰窩形成が認められ

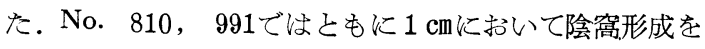
認めるのみで, $2 \mathrm{~cm}$ に拝いてはいずれの変化も認められ

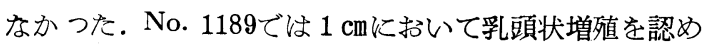
たが, $2 \mathrm{~cm}$ に挄いてはいずれの変化も認められず, No. 1256 では $1 \mathrm{~cm}$ に扮いて乳頭状増殖及び陰窩形成が認めら れたが，2 cmに捻いては変化を認めなかつた. No. 1387
では $1 \mathrm{~cm}$ 及び $2 \mathrm{~cm}$ ともにいずれの変化も示さず, No. 14 $92 て ゙ は 1 \mathrm{~cm}$ において乳頭状增殖の及が認められ， $2 \mathrm{~cm}$

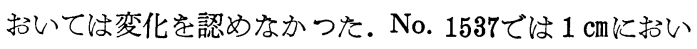
て粘膜下浸潤及び陰窩形成を認めたが，2 cmに执いては 陰窩形成のみが認められた. No. 1876, 1888ではいずれ も $1 \mathrm{~cm}$ に掞いて粘膜下浸潤, 乳頭状増殖及び陰窩形成を

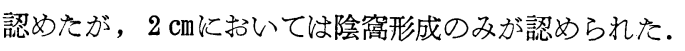
No. $1897 て ゙ は ~ 1 \mathrm{~cm}$ において乳頭状增殖及び陰窩形成を認

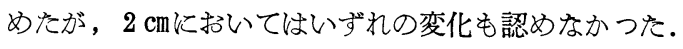

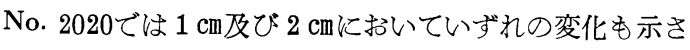
なかつたが, No. 2022では粘膜下浸潤, 乳頭状増殖及び 陰窩形成が $1 \mathrm{~cm}$ 及び $2 \mathrm{~cm}$ ともに認められた. No. 2049で は $1 \mathrm{~cm}$ に捛いて粘膜下浸潤を認め, No. 2073ではやはり

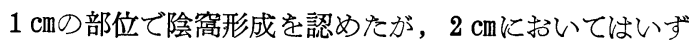

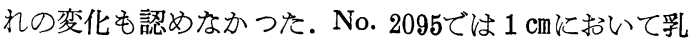
頭状增殖及び陰窩形成が, $2 \mathrm{~cm}$ においては粘膜下浸潤, 乳頭状増殖及び陰窝形成が認められた. No. 2167ではい ずれの変化も示さなかつたが, No. $2198 て ゙ は ~ 1 \mathrm{cm及び2}$

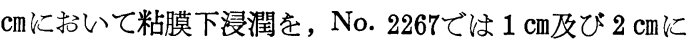

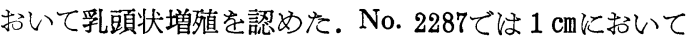
粘膜下浸潤, 乳頭状増殖及び陰窩形成がともに認められ たが， $2 \mathrm{~cm}$ に㧤いてはいずれの変化も認められなかつ た. No. 2305では $1 \mathrm{~cm}$ に掠いていずれの変化も認めず, $2 \mathrm{~cm}$ に揖いては陰窩形成を認めるのみであつた. No. 23 16 で $1 \mathrm{~cm}$ に扣いて乳頭状増殖を, $2 \mathrm{~cm}$ に执いて粘膜下

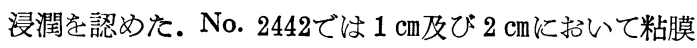

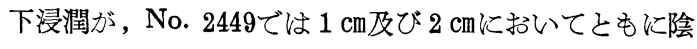

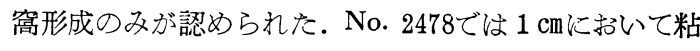
膜下浸潤を, $2 \mathrm{~cm}$ においては陰窩形成のみを認め, No. $2766 て ゙ は 1 \mathrm{~cm}$ 及び $2 \mathrm{~cm}$ に沶いていずれの変化も認めなか つた. No. 2778では $1 \mathrm{~cm}$ において陰窩形成を認めるのみ で, $2 \mathrm{~cm}$ に执いては変化を認めなかつた.

以上の成績を綜合してみると， $1 \mathrm{~cm}$ 亿执いて粘膜浸潤 は21例, 乳頭状增殖は24例, 陰简形成は22例を示し, 2 $\mathrm{cm}$ に拉いて粘膜下浸潤は 6 例, 乳頭状増殖は 6 例, 陰窩 形成は11例を示した。

ii 膀胱全摘除例

腫瘍縁より $1 \mathrm{~cm}$ 及び $2 \mathrm{~cm}$ 部位までの検索は 25 例全例 に，また $3 \mathrm{~cm}$ 部位まで検索しえたのは22例である（表 8 ).

まず検索が $1 \mathrm{~cm}$ 及び $2 \mathrm{~cm}$ の部位にとどまつた 3 症例に

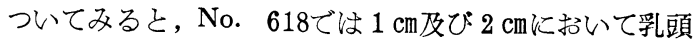

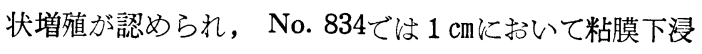


表 8 膀胼全摘除例の腫瘍縁より一定距離に扣ける变化

\begin{tabular}{|c|c|c|c|c|c|c|c|c|c|c|c|}
\hline \multirow{2}{*}{$\begin{array}{ll}\text { 症 } & \text { 例 } \\
\text { 番 }\end{array}$} & \multirow[b]{2}{*}{ 細 胞 型 } & \multirow[b]{2}{*}{ 浸潤度 } & \multicolumn{3}{|c|}{$1 \mathrm{~cm}$} & \multicolumn{3}{|c|}{$2 \mathrm{~cm}$} & \multicolumn{3}{|c|}{$3 \mathrm{~cm}$} \\
\hline & & & $\begin{array}{l}\text { 粘膜下 } \\
\text { 浸 }\end{array}$ & $\begin{array}{l}\text { 乳頭状 } \\
\text { 增 殖 }\end{array}$ & 陰简形成 & $\begin{array}{l}\text { 粘膜下 } \\
\text { 漫 }\end{array}$ & $\begin{array}{l}\text { 乳頭状 } \\
\text { 增 殖 }\end{array}$ & 陰窩形成 & $\begin{array}{l}\text { 粘膜下 } \\
\text { 蔓 }\end{array}$ & $\begin{array}{l}\text { 乳頭状 } \\
\text { 增 殖 }\end{array}$ & 陰窩形成 \\
\hline 618 & 移行上皮 & A & - & + & - & - & + & - & & & \\
\hline 834 & 移行上皮 & $B_{1}$ & + & + & - & - & - & - & & & \\
\hline 1192 & 扁平上皮 & $\mathrm{C}$ & + & - & - & + & - & - & & & \\
\hline 432 & 移行上皮 & $B_{1}$ & + & + & - & - & + & + & - & + & - \\
\hline 708 & 移行上皮 & $\mathrm{B}_{2}$ & + & + & + & + & + & + & + & + & - \\
\hline 779 & 移行上皮 & $\mathrm{B}_{2}$ & + & + & - & + & + & - & - & - & - \\
\hline 882 & 移行上皮 & $\mathrm{B}_{1}$ & - & + & + & - & - & - & - & + & - \\
\hline 974 & 移行上皮 & $\mathrm{A}$ & + & + & + & - & - & - & - & - & - \\
\hline 1060 & 移行上皮 & A & + & + & + & - & - & + & - & - & - \\
\hline 1072 & 移行上皮 & A & - & + & - & - & - & - & - & - & - \\
\hline 1320 & 移行上皮 & $\mathrm{B}_{2}$ & + & + & + & - & - & + & - & - & + \\
\hline 1504 & 扁平上皮 & $\mathrm{C}$ & + & + & - & + & + & - & - & - & + \\
\hline 1527 & 移行上皮 & $\mathrm{C}$ & - & + & - & + & - & - & - & - & + \\
\hline 1546 & 移行上皮 & $\mathrm{B}_{2}$ & + & + & - & + & + & + & - & + & + \\
\hline 1678 & 移行上皮 & $\mathrm{C}$ & + & + & - & + & - & - & - & - & - \\
\hline 1711 & 移行上皮 & A & - & + & + & - & - & + & - & - & - \\
\hline 1804 & 移行上皮 & $\mathrm{C}$ & - & + & - & - & + & - & - & - & - \\
\hline 1938 & 移行上皮 & $\mathrm{C}$ & + & + & - & + & + & - & + & + & - \\
\hline 1951 & 移行上皮 & $\mathrm{C}$ & + & + & - & - & + & + & - & - & - \\
\hline 1971 & 未分化細胞 & $\mathrm{C}$ & + & - & - & + & - & + & - & - & - \\
\hline 2278 & 移行上皮 & $\mathrm{B}_{2}$ & - & + & + & + & - & + & + & + & - \\
\hline 2317 & 移行上皮 & $\mathrm{B}_{2}$ & + & + & + & + & + & + & + & + & + \\
\hline 2320 & 移行上皮 & $\mathrm{A}$ & + & + & + & + & + & + & + & + & + \\
\hline 2598 & 移行上皮 & $\mathrm{A}$ & - & - & - & - & - & + & - & + & + \\
\hline 2842 & 移行上皮 & $\mathrm{C}$ & + & - & + & + & - & - & + & - & + \\
\hline
\end{tabular}

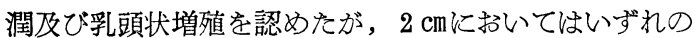
変化も認められなかつた。 また No. $1192 て ゙ は ~ 1 \mathrm{~cm}$ 及び $2 \mathrm{~cm}$ に执いて，いずれも粘膜下浸潤の及が認められた。

つぎに $3 \mathrm{~cm}$ 部位まで 検索しえた 22 例についてみる と, No. $432 て ゙ は ~ 1 \mathrm{~cm}$ に打いて粘膜下浸潤及び乳頭状増 殖を， $2 \mathrm{~cm}$ に抬いては乳頭状増殖及び陰窩形成を， $3 \mathrm{~cm}$ においては乳頭状増殖のみを認めた．No．708では $1 \mathrm{~cm}$ 及び $2 \mathrm{~cm}$ に执いて粘膜下浸潤，乳頭状增殖及び陰窩形成 がともに認められ， $3 \mathrm{~cm}$ に扔いては粘膜下浸潤及び乳頭

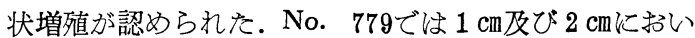

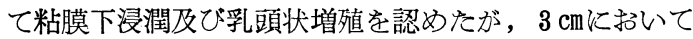

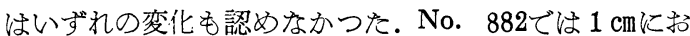
いて乳頭状増殖及び陰窩形成を，2 cmに扣いてはいずれ

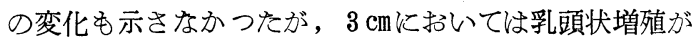
認められた. No. 974では $1 \mathrm{~cm}$ に抬いて粘膜下浸潤, 乳

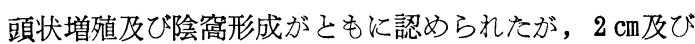

$3 \mathrm{~cm}$ に抢いてはいずれの変化も認められなかつた. No. 1060 では $1 \mathrm{~cm}$ に掞いて粘膜下浸潤, 乳頭状増殖及び陰䆚 形成がともに認められたが， $2 \mathrm{~cm}$ に打いては陰窩形成の

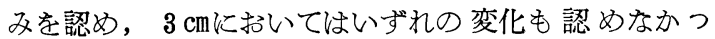
た. No. 1072では $1 \mathrm{~cm}$ に执いて乳頭状増殖を示したの及

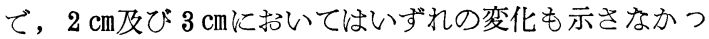
た. No. 1320では $1 \mathrm{~cm}$ に扔いて粘膜下浸潤, 乳頭状増殖

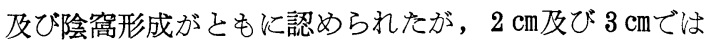

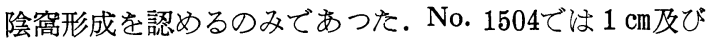
$2 \mathrm{~cm}$ に扣いて粘膜下浸潤及び乳頭状増殖を認めたが， 3 cmに扮いては陰窩形成を認めるのみであつた. No. 1527 では $1 \mathrm{~cm}$ に执いて乳頭状増殖を, $2 \mathrm{~cm}$ に执いては粘膜下 浸潤を，3 cmに括いては陰窩形成を認めるのみであつ

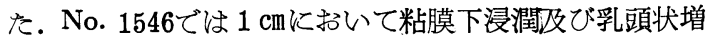
殖を, $2 \mathrm{~cm}$ に扮いては粘膜下浸潤, 乳頭状增殖及び陰窩 形成を, $3 \mathrm{~cm}$ に掞いては乳頭状増殖及び陰窩形成を認め 
た. No. 1678では $1 \mathrm{~cm}$ に执いて粘膜下浸潤及び乳頭状増 殖が, $2 \mathrm{~cm}$ 深いては粘膜下浸潤が認められたが， $3 \mathrm{~cm}$ においてはいずれの変化も認められなかつた. No. 1711 では $1 \mathrm{~cm}$ に掞いて乳頭状増殖及び陰窩形成を, $2 \mathrm{~cm}$ に拉 いては陰窩形成を認めたが， $3 \mathrm{~cm}$ にいてはいずれの変

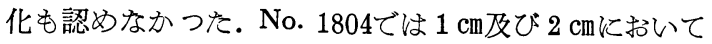
乳頭状増殖を示すの及で， $3 \mathrm{~cm}$ においてはいずれの変化

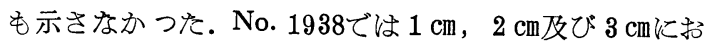
いてともに粘膜下浸潤及び乳頭状增殖が 認められた。

No. $1951 て ゙ は 1 \mathrm{~cm}$ にいて粘膜下浸潤及び乳頭状増殖 を, $2 \mathrm{~cm}$ に打いては乳頭状増殖及び陰窩形成を認めた が, $3 \mathrm{~cm}$ にいてはいずれの変化も認めなかつた. No. 1971では $1 \mathrm{~cm}$ に打いて粘膜下浸潤を, $2 \mathrm{~cm}$ に执いて粘膜 下浸潤及び陰窩形成を認めたが，3 cmに怙いてはいずれ

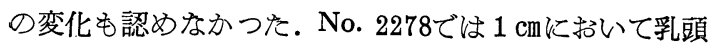
状增殖及び陰窩形成が， $2 \mathrm{~cm}$ に括いて粘膜下浸潤及び陰 窩形成が， $3 \mathrm{~cm}$ に扢いて粘膜下浸潤及び乳頭状増殖が認 められた. No. 2317，2320では $1 \mathrm{~cm}, 2 \mathrm{~cm}$ 及び $3 \mathrm{~cm}$ にお いて粘膜下浸潤, 乳頭状増殖及び陰窩形成がともに認め

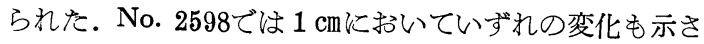
ず, $2 \mathrm{~cm}$ に打いて陰窩形成を, $3 \mathrm{~cm}$ に打いて乳頭状増殖

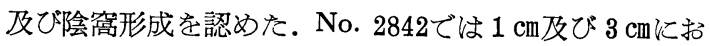
いて粘膜下浸潤及び陰窩形成が認められたが， 2 cmにお いては粘膜下浸潤が認められるのみであつた。

以上の成績を綜合してみると，1 cmに掞いて粘膜下浸 潤は17例, 乳頭状增殖は 21 例, 陰窩形成は10例を示し, また $2 \mathrm{~cm}$ に掞いて粘膜下浸潤は13例, 乳頭状増殖は11 例，陰窩形成は12例を示した。ささらに $3 \mathrm{~cm}$ に扢いては粘 膜下浸潤を 6 例, 乳頭状增殖を 9 例, 陰窩形成を 8 例に 認めた。
2 睡瘍部における浸潤度と周囲の変化との関係

i 膀胱部分切除例

表 9 のごとく, まず $1 \mathrm{~cm}$ の部位における浸潤度と周团 の関係をみると, 粘膜下浸潤は浸潤度 Aで 24 例中 6 例 (25.0\%) を示し, $\mathrm{B}_{1}$ では18例中11例 $(61.1 \%), \mathrm{B}_{2}$ 及 びCでは 3 例中 2 例 $(66.6 \%)$ に認められた. 乳頭状增 殖は浸潤度 $\mathrm{A} て ゙ 10$ 例 (41.6\%), $\mathrm{B}_{1}$ でも10例 (55.5\%), $\mathrm{B}_{2}$ で 3 例 ( $\left.100.0 \%\right), \mathrm{C} て ゙ は 1$ 例 $(33.3 \%)$ 飞認めら れた。 また陰窩形成は浸潤度 $\mathrm{A} て ゙ 12$ 例 $(50.0 \%), \mathrm{B}_{1}$ では

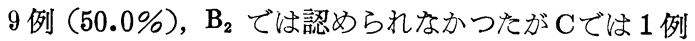
(33.3\%) 飞認められた.

さらに $2 \mathrm{~cm}$ に扮ける変化についてみると, 粘膜下浸潤 は浸潤度Aで18例中 1 例 ( $5.5 \%)$ を示し， $B_{1}$ では12

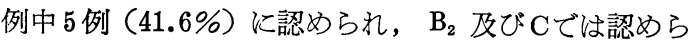

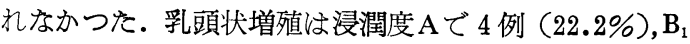
では 2 例 $(16.6 \%)$ を示したが, $\mathrm{B}_{2}$ 及び Cでは変化を認 めなかつた。 また陰窩形成は浸潤度 $\mathrm{A} て ゙ 6$ 例 (33.3\%),

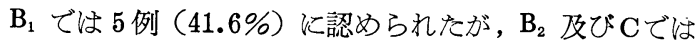
変化を認めなかつた。

ii 膀胱全摘除例

表10のごとく,まず $1 \mathrm{~cm}$ 部位に抢ける浸潤度と周囲 の組織学的変化この関係をみると, 粘膜下浸潤は浸潤度 $\mathrm{A}$ では 7 例中 3 例で $42.8 \%$ を示し, $\mathrm{B}_{1}$ では 3 例中 2 例 $(66.6 \%), \mathrm{B}_{2}$ では 6 例中 5 例 $(83.3 \%), \mathrm{C} て ゙ は 9$ 例 中 7 例 $(77.7 \%)$ 飞認められた。乳頭状增殖は浸潤度A で6例 (85.7\%), $\mathrm{B}_{1}$ では 3 例 ( $\left.100.0 \%\right), \mathrm{B}_{2}$ で 6 例 (100.0\%), Cでは 6 例 $(66.6 \%)$ を示した。また陰窩形 成は浸潤度 Aで 4 例 $(57.1 \%), B_{1}$ では 1 例 (33.3\%), $\mathrm{B}_{2}$ で 4 例 $(66.6 \%), \mathrm{C} て ゙ は 1$ 例 $(11.1 \%)$ に認められ た.

表 9 膀脱部分切除例における浸潤度と腫瘍周因の变化との関係

\begin{tabular}{|c|c|c|c|c|c|c|c|c|}
\hline \multirow{2}{*}{ 浸潤度 } & \multicolumn{4}{|c|}{$\mathrm{cm}$} & \multicolumn{4}{|c|}{$\mathrm{cm}$} \\
\hline & 検索例数 & $\begin{array}{l}\text { 粘膜下 } \\
\text { 漫 潤 }\end{array}$ & $\begin{array}{l}\text { 乳頭状 } \\
\text { 增 殖 }\end{array}$ & 陰简形成 & 検索例数 & $\begin{array}{l}\text { 粘膜下 } \\
\text { 浸 潤 }\end{array}$ & $\begin{array}{l}\text { 乳頭状 } \\
\text { 増 殖 }\end{array}$ & 陰窩形成 \\
\hline A & 24 & $\begin{array}{c}6 \\
(25.0) \\
\end{array}$ & $\begin{array}{c}10 \\
(41.6) \\
\end{array}$ & $\begin{array}{c}12 \\
(50.0) \\
\end{array}$ & 18 & $\begin{array}{c}1 \\
(5.5)\end{array}$ & $\begin{array}{c}4 \\
(22.2)\end{array}$ & $\begin{array}{c}6 \\
(33.3)\end{array}$ \\
\hline $\mathrm{B}_{1}$ & 18 & $\begin{array}{c}11 \\
(61.1) \\
\end{array}$ & $\begin{array}{c}10 \\
(55.5) \\
\end{array}$ & $\begin{array}{c}9 \\
(50.0) \\
\end{array}$ & 12 & $\begin{array}{c}5 \\
(41.6) \\
\end{array}$ & $\begin{array}{c}2 \\
(16.6) \\
\end{array}$ & $\begin{array}{c}5 \\
(41.6) \\
\end{array}$ \\
\hline $\mathbf{B}_{2}$ & 3 & $\begin{array}{c}2 \\
(66.6) \\
\end{array}$ & $\begin{array}{c}3 \\
(100.0) \\
\end{array}$ & $\begin{array}{l}0 \\
(0)\end{array}$ & 1 & $\begin{array}{l}0 \\
(0)\end{array}$ & $\left(\begin{array}{l}0 \\
0\end{array}\right)$ & $\left(\begin{array}{l}0 \\
0\end{array}\right)$ \\
\hline $\mathrm{C}$ & 3 & $\begin{array}{c}2 \\
(66.6) \\
\end{array}$ & $\begin{array}{c}1 \\
(33.3) \\
\end{array}$ & $\begin{array}{c}1 \\
(33.3)\end{array}$ & 1 & $\begin{array}{l}0 \\
(0) \\
\end{array}$ & $\begin{array}{l}0 \\
(0) \\
\end{array}$ & $\begin{array}{l}0 \\
(0)\end{array}$ \\
\hline 計 & 48 & 21 & 24 & 22 & 32 & 6 & 6 & 11 \\
\hline
\end{tabular}

（）内は検索例数に対する百分率を示す 
表10 膀胱全摘除例における浸潤度と腫瘍周囲の変化との関俰

\begin{tabular}{|c|c|c|c|c|c|c|c|c|c|c|c|c|}
\hline \multirow[b]{2}{*}{ 浸潤度 } & \multicolumn{4}{|c|}{$\mathrm{cm}$} & \multicolumn{4}{|c|}{$\mathrm{cm}$} & \multicolumn{4}{|c|}{$\mathrm{cm}$} \\
\hline & 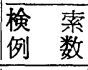 & \begin{tabular}{|l} 
粘膜下 \\
漫 潤
\end{tabular} & $\begin{array}{l}\text { 乳頭状 } \\
\text { 㙼 殖 }\end{array}$ & $\begin{array}{ll}\text { 㟏 } & \text { 窩 } \\
\text { 形 } & \text { 成 }\end{array}$ & 検 & $\begin{array}{l}\text { 粘膜下 } \\
\text { 漫 潤 }\end{array}$ & $\begin{array}{l}\text { 乳頭状 } \\
\text { 殖 }\end{array}$ & $\begin{array}{ll}\text { 㟏 } & \text { 窩 } \\
\text { 形 } & \text { 成 }\end{array}$ & 検 & $\begin{array}{l}\text { 粘膜下 } \\
\text { 浸 潤 }\end{array}$ & $\begin{array}{l}\text { 乳頭 状 } \\
\text { 増 殖 }\end{array}$ & $\begin{array}{ll}\text { 䧔 } & \text { 䆚 } \\
\text { 形 } & \text { 成 }\end{array}$ \\
\hline $\mathbf{A}$ & 7 & $\begin{array}{c}3 \\
(42.8)\end{array}$ & $\begin{array}{c}6 \\
(85.7)\end{array}$ & $\begin{array}{c}4 \\
(57.1)\end{array}$ & 7 & $\begin{array}{c}1 \\
(14.3)\end{array}$ & $\begin{array}{c}2 \\
(28.6)\end{array}$ & $\begin{array}{c}4 \\
(57.1)\end{array}$ & 6 & $\begin{array}{c}1 \\
(16.6)\end{array}$ & $\begin{array}{c}2 \\
(33.3)\end{array}$ & $\begin{array}{c}2 \\
(33.3)\end{array}$ \\
\hline$B_{1}$ & 3 & $\begin{array}{c}2 \\
(66.6)\end{array}$ & $\begin{array}{c}3 \\
(100.0) \\
\end{array}$ & $\begin{array}{c}1 \\
(33.3) \\
\end{array}$ & 3 & $\begin{array}{l}0 \\
(0) \\
\end{array}$ & $\begin{array}{c}1 \\
(33.3) \\
\end{array}$ & $\begin{array}{c}1 \\
(33.3)\end{array}$ & 2 & $\begin{array}{l}0 \\
0\end{array}$ & $\begin{array}{c}2 \\
(100.0)\end{array}$ & $\begin{array}{l}0 \\
(0)\end{array}$ \\
\hline $\mathbf{B}_{2}$ & 6 & $\begin{array}{c}5 \\
(83.3)\end{array}$ & $\begin{array}{c}6 \\
(100.0)\end{array}$ & $\begin{array}{c}4 \\
(66.6)\end{array}$ & 6 & $\begin{array}{c}5 \\
(83.3)\end{array}$ & $\begin{array}{c}4 \\
(66.6)\end{array}$ & $\begin{array}{c}5 \\
(83.3)\end{array}$ & 6 & $\begin{array}{c}3 \\
(50.0)\end{array}$ & $\begin{array}{c}4 \\
(66.6)\end{array}$ & $\begin{array}{c}3 \\
(50.0)\end{array}$ \\
\hline C & 9 & $\begin{array}{c}7 \\
(77.7) \\
\end{array}$ & $\begin{array}{c}6 \\
(66.6) \\
\end{array}$ & $\begin{array}{c}1 \\
(11.1)\end{array}$ & 9 & $\begin{array}{c}7 \\
(77.7)\end{array}$ & $\begin{array}{c}4 \\
(44.4) \\
\end{array}$ & $\begin{array}{c}2 \\
(22.2) \\
\end{array}$ & 8 & $\begin{array}{c}2 \\
(25.0) \\
\end{array}$ & $\begin{array}{c}1 \\
(12.5) \\
\end{array}$ & $\begin{array}{c}3 \\
(37.5)\end{array}$ \\
\hline 計 & 25 & 17 & 21 & 10 & 25 & 13 & 11 & 12 & 22 & 6 & 9 & 8 \\
\hline
\end{tabular}

（）内は検索例数に対する百分率を示す

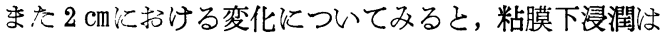
浸潤度Aでは 7 例中 1 例で14.3\%を示したが， $\mathrm{B}_{1}$ では 変化を認めず, $\mathrm{B}_{2}$ では 6 例中 5 例 $(83.3 \%), \mathrm{C} て ゙ 9$ 例 中 7 例 $(77.7 \%)$ 飞認められた。乳頭状増殖法浸潤度 $\mathrm{A}$ で 2 例 $(28.6 \%), B_{1}$ で 1 例 $(33.3 \%), B_{2}$ で 4 例 $(66.6$ \%), Cでも 4 例 (44.4\%) を示した. また陰䆚形成は浸 潤度Aでは 4 例 (57.1\%), B

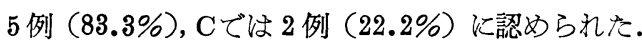

さらに $3 \mathrm{~cm}$ に扮ける变化を及ると, 粘膜下浸潤は浸潤 度 $\mathrm{A} て ゙ 6$ 例中 1 例 $(16.6 \%)$ を示したが， $\mathrm{B}_{1}$ では変化 を認めなかつた。しかし $\mathrm{B}_{2}$ では 6 例中 3 例 $(50.0 \%)$, Cで 8 例中 2 例 $(25.0 \%)$ 飞認められた。乳頭状增殖は 浸潤度Aで 2 例 (33.3\%)，B $\mathrm{B}_{1}$ では 2 例 ( $\left.100.0 \%\right), \mathrm{B}_{2}$ では 4 例 $(66.6 \%), \mathrm{C} て ゙ 1$ 例 $(12.5 \%)$ 飞変化が認めら れた。また陰窩形成は浸潤度 $\mathrm{A} て ゙ 2$ 例 $(33.3 \%)$ を示し

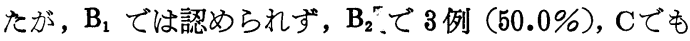
3 例 $(37.5 \%)$ に認められた。

3 腫瑒周囲に扔ける粘膜下浸潤の程度

腫瘍周囲に抬ける粘膜下浸潤の程度を観察したが, そ の程度の基準も Jewett の分類と同様に判定した. しか
し腫瘍部の最高浸潤度と区別するために, 腫瘍周团の浸 潤度は便宣上 $a, b_{1}, b_{2}, c$ を用いた。

\section{i 膀胱部分切除例}

表11のこととく, 腫湯部最高浸潤度 $\mathrm{A} の 1 \mathrm{~cm}$ 部位に揖 ける浸潤例数は 6 例, $2 \mathrm{~cm}$ では 1 例であるが, この部位 の浸潤度はいずれもaを示した。

最高浸潤度 $\mathrm{B}_{1}$ の $1 \mathrm{~cm}$ の部位に执りる浸潤例数は11例， であり， 7 例が a， 4 例が $\mathrm{b}_{1}$ を示し，また $2 \mathrm{cmでは} 5$ 例であり， 3 例が $a ， 2$ 例が b, を示した。

最高浸潤度 $\mathrm{B}_{2}$ の $1 \mathrm{~cm}$ の部位に捛ける浸潤例数快 2 例 であり，この部の浸潤度流いずれも a を示した。しかし $2 \mathrm{~cm}$ 部位には浸潤が認められなかつた。

最高浸潤度 $\mathrm{C} の 1 \mathrm{~cm}$ の部位に捛ける浸潤例数は 2 例で あり， $\mathrm{b}_{1}, \mathrm{c}$ が夫ふ 1 例を示した。しかし $2 \mathrm{~cm}$ 部位に は浸潤が認められなかつた。

すなわち， $1 \mathrm{~cm}$ 部位では浸潤例数が 21 例であり，こ のうち a は15例で71.4\%を示し，b，は 5例 $(23.8 \%) ;, c$ は 1 例 ( $4.8 \%)$ を示した。 ま江 $2 \mathrm{~cm}$ 部位では浸潤例 数が 6 例であり, a は 4 例 $(66.7 \%), b_{1}$ は 2 例（33.3\% \%) に認められた。

表11 膀胱部分切除例における腫瘍周囲の浸潤度

\begin{tabular}{|c|c|c|c|c|c|c|c|c|c|c|}
\hline \multirow{2}{*}{$\begin{array}{l}\text { 腫 瘍 部 } \\
\text { 最高浸潤度 }\end{array}$} & \multicolumn{5}{|c|}{$1 \mathrm{~cm}$ の部位の浸潤度 } & \multicolumn{5}{|c|}{$2 \mathrm{~cm}$ の部位の浸潤度 } \\
\hline & $\begin{array}{ll}\text { 浸 } & \text { 潤 } \\
\text { 例 数 }\end{array}$ & $\mathrm{a}$ & $\mathrm{b}_{1}$ & $\mathrm{~b}_{2}$ & c & $\begin{array}{ll}\text { 浸 潤 } \\
\text { 例 数 }\end{array}$ & $\mathrm{a}$ & $\mathrm{b}_{1}$ & $\mathrm{~b}_{2}$ & c \\
\hline A & 6 & 6 & 0 & 0 & 0 & 1 & 1 & 0 & 0 & 0 \\
\hline $\mathbf{B}_{1}$ & 11 & 7 & 4 & 0 & 0 & 5 & 3 & 2 & 0 & 0 \\
\hline $\mathrm{B}_{2}$ & 2 & 2 & 0 & 0 & 0 & 0 & 0 & 0 & 0 & 0 \\
\hline $\mathrm{C}$ & 2 & 0 & 1 & 0 & 1 & 0 & 0 & 0 & 0 & 0 \\
\hline $\begin{array}{l}\text { 計 } \\
\%\end{array}$ & 21 & $\begin{array}{c}15 \\
71.4\end{array}$ & $\begin{array}{c}5 \\
23.8 \\
\end{array}$ & $\begin{array}{l}0 \\
0\end{array}$ & $\begin{array}{c}1 \\
4.8 \\
\end{array}$ & 6 & $\begin{array}{c}4 \\
66.7\end{array}$ & $\begin{array}{c}2 \\
33.3\end{array}$ & $\begin{array}{l}0 \\
0\end{array}$ & $\begin{array}{l}0 \\
0\end{array}$ \\
\hline
\end{tabular}


表12膀脱全摘除例における腫瘍周囲の浸潤度

\begin{tabular}{|c|c|c|c|c|c|c|c|c|c|c|c|c|c|c|c|}
\hline \multirow{2}{*}{$\begin{array}{lll}\text { 腫 } & \text { 瘍 } & \text { 部 } \\
\text { 最高浸潤度 }\end{array}$} & \multicolumn{5}{|c|}{$1 \mathrm{~cm}$ 部位の浸潤度 } & \multicolumn{5}{|c|}{$2 \mathrm{~cm}$ の部位の浸潤度 } & \multicolumn{5}{|c|}{$3 \mathrm{~cm}$ 部位の浸潤度 } \\
\hline & 浸潤例数 & a & $\mathrm{b}_{1}$ & $\mathrm{~b}_{2}$ & c & 浸潤例数 & a & $\mathrm{b}_{1}$ & $\mathrm{~b}_{2}$ & c & 浸潤例数 & $a$ & $b_{1}$ & $\mathrm{~b}_{2}$ & c \\
\hline $\mathrm{A}$ & 3 & 3 & 0 & 0 & 0 & 1 & 1 & 0 & 0 & 0 & 1 & 1 & 0 & 0 & 0 \\
\hline $\mathbf{B}_{1}$ & 2 & 2 & 0 & 0 & 0 & 0 & 0 & 0 & 0 & 0 & 0 & 0 & 0 & 0 & 0 \\
\hline $\mathrm{B}_{2}$ & 5 & 5 & 0 & 0 & 0 & 5 & 5 & 0 & 0 & 0 & 3 & 3 & 0 & 0 & 0 \\
\hline $\mathrm{C}$ & 7 & 2 & 4 & 0 & 1 & 7 & 6 & 0 & 0 & 1 & 2 & 1 & 0 & 0 & 1 \\
\hline $\begin{array}{l}\text { 計 } \\
\%\end{array}$ & 17 & $\left|\begin{array}{c}12 \\
70.7\end{array}\right|$ & $\begin{array}{c}4 \\
23.5 \\
\end{array}$ & $\begin{array}{l}0 \\
0 \\
\end{array}$ & $\begin{array}{c}1 \\
5.8 \\
\end{array}$ & 13 & $\begin{array}{c}12 \\
92.3\end{array}$ & $\begin{array}{l}0 \\
0\end{array}$ & $\begin{array}{l}0 \\
0\end{array}$ & $\begin{array}{c}1 \\
7.7 \\
\end{array}$ & 6 & \begin{tabular}{|c|}
5 \\
83.3
\end{tabular} & $\begin{array}{l}0 \\
0\end{array}$ & $\begin{array}{l}0 \\
0\end{array}$ & $\begin{array}{c}1 \\
16.7\end{array}$ \\
\hline
\end{tabular}

表13 膀䏚部分切除例の腫瘍縁より一定距離における变化

\begin{tabular}{|c|c|c|c|c|c|c|c|c|}
\hline \multirow{2}{*}{ 例 } & \multicolumn{4}{|c|}{$1 \quad \mathrm{~cm}$} & \multicolumn{4}{|c|}{$2 \quad \mathrm{~cm}$} \\
\hline & 検索例数 & $\begin{array}{l}\text { 粘 膜 下 } \\
\text { 漫 }\end{array}$ & $\begin{array}{l}\text { 乳頭 状 } \\
\text { 增 殖 }\end{array}$ & 陰窩形成 & 検索例数 & $\begin{array}{l}\text { 粘 膜 下 } \\
\text { 浸 }\end{array}$ & $\begin{array}{l}\text { 乳 頭 状 } \\
\text { 增 }\end{array}$ & 陰窝形成 \\
\hline 48 & 48 & $\begin{array}{c}21 \\
(43.7)\end{array}$ & $\begin{array}{c}24 \\
(50.0)\end{array}$ & $\begin{array}{c}22 \\
(45.8)\end{array}$ & 32 & $\begin{array}{c}6 \\
(18.7)\end{array}$ & $\begin{array}{c}6 \\
(18.7)\end{array}$ & $\begin{array}{c}11 \\
(34.4)\end{array}$ \\
\hline
\end{tabular}

表14 膀胱全摘除例の腫瘍緑より一定距離における变化

\begin{tabular}{|c|c|c|c|c|c|c|c|c|c|c|c|c|}
\hline \multirow{2}{*}{ 例 娄 } & \multicolumn{4}{|c|}{$\mathrm{cm}$} & \multicolumn{4}{|c|}{$\mathrm{cm}$} & \multicolumn{4}{|c|}{$\mathrm{cm}$} \\
\hline & $\begin{array}{ll}\text { 検 } \\
\text { 素 } \\
\text { 数 }\end{array}$ & \begin{tabular}{|l|} 
粘膜下 \\
漫 潤
\end{tabular} & $\begin{array}{l}\text { 乳頭状 } \\
\text { 增 }\end{array}$ & $\mid$ 陰窝形成| & $\begin{array}{ll}\text { 棆 } & \text { 索 } \\
\text { 数 }\end{array}$ & 粘膜下 & $\begin{array}{l}\text { 乳頭状 } \\
\text { 增殖 }\end{array}$ & $\mid$ 陰窩形成 & $\begin{array}{ll}\text { 検 } & \text { 䨬 } \\
\text { 数 }\end{array}$ & $\begin{array}{l}\text { 粘膜下 } \\
\text { 漫 潤 }\end{array}$ & $\begin{array}{l}\text { 乳頭状 } \\
\text { 增 殖 }\end{array}$ & \\
\hline 25 & 25 & $\begin{array}{c}17 \\
(68.0)\end{array}$ & $\begin{array}{c}21 \\
(84.0)\end{array}$ & $\begin{array}{c}10 \\
(40.0) \\
\end{array}$ & 25 & $\begin{array}{c}13 \\
(52.0) \\
\end{array}$ & $\begin{array}{c}11 \\
(44.0)\end{array}$ & $\begin{array}{c}12 \\
(48.0)\end{array}$ & 22 & $\begin{array}{c}6 \\
(27.3)\end{array}$ & $\begin{array}{c}9 \\
(40.9)\end{array}$ & $\begin{array}{c}8 \\
(36.4)\end{array}$ \\
\hline
\end{tabular}

\section{ii 膀胱全摘除例}

表12のごとく, 腫瘍部最高浸潤度 $\mathrm{A} の 1 \mathrm{~cm}$ 部位にお ける浸潤例数は 3 例, $2 \mathrm{~cm}$ 及び $3 \mathrm{~cm}$ では夫ふ 1 例を示し たが，いずれも a と判定された。

最高浸潤度 $\mathrm{B}_{1}$ の $1 \mathrm{~cm}$ の部位に扮ける浸潤例は 2 例で

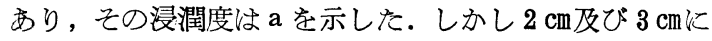
法浸潤が認められなかつた。

最高浸潤度 $\mathrm{B}_{2}$ の $1 \mathrm{~cm}$ 及び $2 \mathrm{~cm}$ の部位に扮ける浸潤例 数は夫々 5 例づつであり，いずれも $\mathrm{a}$ を示し，また $3 \mathrm{~cm}$ でも 3 例に認められたが，いずれもaであつた。

最高浸潤度 $\mathrm{C} の 1 \mathrm{~cm}$ の部位に抬ける浸潤例数恃 7 例で あり， 2 例が a ， 4 例が $\mathrm{b}_{1}, 1$ 例が c を示した。 また 2 cmであ 7 例であり， 6 例が a， 1 例が c であつた。 さら 飞 $3 \mathrm{~cm}$ では 1 例が $\mathrm{a}$ ，他の 1 例は $\mathrm{c}$ を示した.

すふわち，1 cmの部位では浸潤例数が17例であり，a は12例で70.7\%を示し， $\mathrm{b}_{1}$ は 4 例 $(23.5 \%), \mathrm{c}$ は 1 例 ( $5.8 \%)$ であり，また $2 \mathrm{~cm}$ 部位に扮いては浸潤例数 は13例であり，a 柱12例 (92.3\%), c は 1例 ( $7.7 \%)$, さらに $3 \mathrm{~cm}$ 部位に执いては 6 例で, そのうちa は 5 例
(83.3\%), c は 1 例 (16.7\%) を示した。

\section{4 小括}

以上の成績を綜合してみると，まず膀胱部分切除例の 腫瘍辺縁に打ける变化は, $1 \mathrm{~cm}$ 部位で粘膜下浸潤过 21 例 $(43.7 \%)$, 乳頭状增殖を 24 例 $(50.0 \%)$, 陰營形成を 22例 $(45.8 \%)$ に認めたが， $2 \mathrm{~cm}$ の部位では粘膜下浸潤 及び 乳頭状増殖を夫々 6 例 $(18.7 \%)$, 陰窩形成を 11例 （34.4\%）に認めるにすぎなかつた（表13）．また全摘除 例では $1 \mathrm{~cm}$ 部位で粘膜下浸潤を17例 (68.0\%), 乳頭状 増殖を 21 例 $(84.0 \%)$ ，陰窩形成を 10 例 $(40.0 \%)$ 飞認

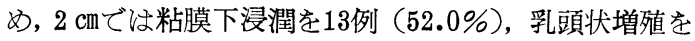
11例 (44.0\%)，陰窩形成は 12 例 (48.0\%) に，さらに

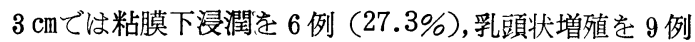
(40.9\%), 陰㸗形成は 8 例 (36.4\%) に認めた（表14). すなわち, 粘膜下浸潤及び乳頭状增殖は腫瘍縁より 2 〜 $3 \mathrm{~cm}$ と離れるにしたがって減少するが，陰窩形成は

1，2，3 cmでは㬄とんご変化のないととがわかる. つぎに浸潤度との関係についてみると，粘膜下浸潤に 执いてのみ浸潤度との間に関係が認められた。すなわ 
ち, 部分切除例に扔いては $1 \mathrm{~cm}$ 部位で腫瘍部の浸潤が $\mathrm{A}$ の場合注 $25.0 \%$ あるが， $\mathrm{B}_{1}$ 以上の例になると 61.1 \% 66.6\%とかなり高率に認められるようになり，また $2 \mathrm{~cm}$ も浸潤度 $\mathrm{B}_{1}$ に㧠いて41.6\%に認められている。 しかし乳頭状増殖及び陰䆚形成は浸潤度による差は湶と んぞ認めなかつた。また全摘除例についてみると， $1 \mathrm{~cm}$ の部位に怙ける粘莫下浸潤は，浸潤度が $\mathrm{B}_{1}, \mathrm{~B}_{2}, \mathrm{C}$ とな るとともに夫々 $66.6 \% ， 83.3 \% ， 77.3 \%$ と高率に認めら れるようになり， $2 \mathrm{cmでも} \mathrm{B}_{2}$ 以上で77.7\% 83.3\%を 示し,さらに $3 \mathrm{~cm} て ゙ も 25.0 〜 50.0 \%$ やはり浸潤度 $\mathrm{A}$ よ り高率に認められている。し六し乳頭状増殖及び陰窩形 成は，浸潤度による差はあまり認められなかつた。

ついで腫場周囲に打ける粘膜下浸潤の状態をみると， 部分切除例に扢いては $1 \mathrm{~cm}$ の部位で粘膜下浸潤（a）を 認めるものは $71.4 \%$ ，筋層半ばまでの浸潤 $\left(\mathrm{b}_{1}\right)$ をみる ものは23.8\%，筋層を越えて浸潤している（c）ものは 4.8\%を示した。また $2 \mathrm{~cm}$ 部位では $\mathrm{a}$ を示したものが

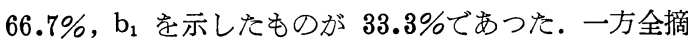
除例に执いては， $1 \mathrm{~cm}$ の部位で a を示したものが 70.7 $\%, \mathrm{~b}_{1}$ を示したものが $23.5 \%, \mathrm{c}$ を示したものが $5.8 \%$

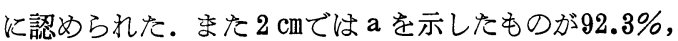
c を示したものが 7.7\%であつた.さらに $3 \mathrm{~cm} ゙$ は $\mathrm{a}$ 示したものが $83.3 \%, c$ を示したものが $16.7 \%$ に認めら れた。すなわち，腫瘍周囲に抢ける粘膜下浸潤はかなり の高頻度で深部に達していることがわかる．また同時に この変化を腫瘍部に抢ける浸潤度と比較検討したとこ 了, 部分切除例では $1,2 \mathrm{~cm}$ ともに $\mathrm{b}_{1}$ 以上の変化はい ずれも腫場部の浸潤度が $\mathrm{B}_{1}$ 以上の例において認められ たが，とくに浸潤度の軽度な $\mathrm{B}_{1}$ においても $1 \mathrm{~cm}$ 部位 で $b_{1}$ が11例中 4 例に, $2 \mathrm{~cm}$ 部位で $b_{1}$ が 5 例中 2 例
表15 膀脱部分切除例に扣ける再発例の細胞型

\begin{tabular}{|c|c|c|c|c|}
\hline 細胞型 & $\begin{array}{l}\text { 移行上 } \\
\text { 皮 型 }\end{array}$ & $\begin{array}{l}\text { 扁平上 } \\
\text { 形 }\end{array}$ & $\begin{array}{l}\text { 未分化 } \\
\text { 細胞型 }\end{array}$ & 計 \\
\hline 例 数 & 6 & 3 & 1 & 10 \\
\hline$\%$ & 60.0 & 30.0 & 10.0 & 100.0 \\
\hline
\end{tabular}

表16 膀胱部分切除例に扣ける再発例の浸潤度

\begin{tabular}{|c|c|c|}
\hline 分 類 & 例 数 & $\%$ \\
\hline $\mathrm{O}$ & 0 & 0 \\
\hline A & 3 & 30.0 \\
\hline $\mathbf{B}_{1}$ & 5 & 50.0 \\
\hline $\mathrm{B}_{2}$ & 0 & 0 \\
\hline $\mathrm{C}$ & 2 & 20.0 \\
\hline 計 & 10 & 100.0 \\
\hline
\end{tabular}

に認められたここはきわめて重要な所見である．また全 摘除例では $b_{1}$ 以上の変化を示したのは $1,2,3 \mathrm{~cm}$ と もに腫瘍部の浸潤度が Cの例に执いて認められた。すな わち浸潤度とともに周囲に扔ける浸潤も高度となるとと を示している.

第 3 節 膀胱部分切除例に损ける再発例の検討 部分切除例の検索例は48例で，このうち再発の認めら れたのは10例であるが，乙れらの標本について再検討を 行った.

\section{1 細胞型及び浸潤度}

移行上皮型は 10 例中 6 例で $60.0 \%$ を示し，扁平上皮型 は 3 例 $(30.0 \%)$,未分化細胞型は 1 例 $(10.0 \%)$ を示し た（表15）。た浸潤度Aは 3 例 $(30.0 \%) ， B_{1}$ は 5 例 (50.0\%), Cは 2 例 (20.0\%) に認められた（表16).

\section{2 睡瘍周囲に招ける病理組織学的検索}

表17 膀腅部分切除例に拈ける再発例の浸潤度と腫瘍周囲の变化との関係

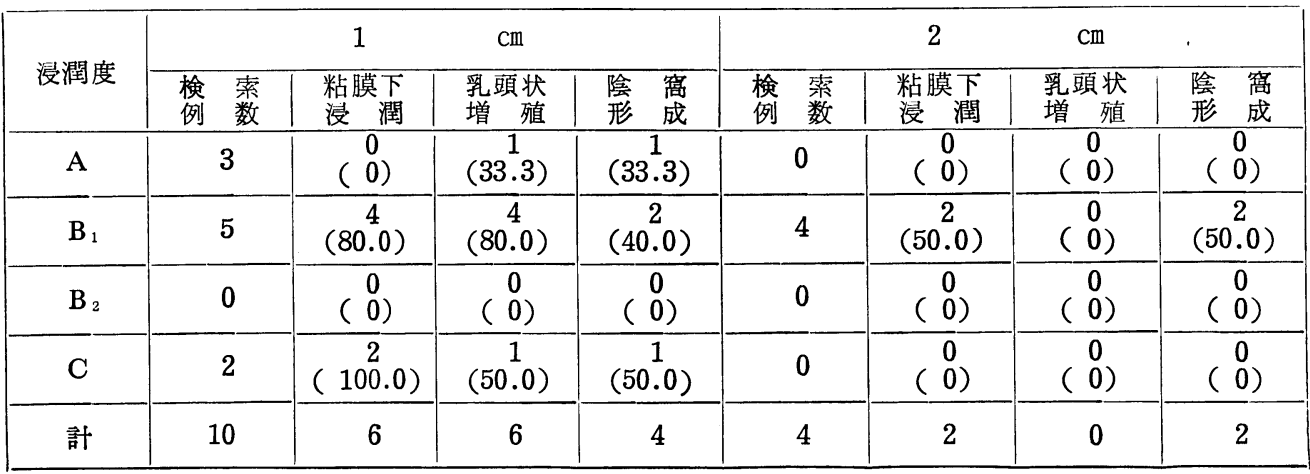

（）内は検索例数に対する百分率を示す. 
表18 膀胱部分切除例における再発例の腫瘍周囲の浸潤度

\begin{tabular}{|c|c|c|c|c|c|c|c|c|c|c|}
\hline \multirow{2}{*}{$\begin{array}{ll}\text { 腫 } & \text { 部 } \\
\text { 最高浸潤度 }\end{array}$} & \multicolumn{5}{|c|}{$1 \mathrm{~cm}$ の部位.の浸潤度 } & \multicolumn{5}{|c|}{$2 \mathrm{~cm}$ 部位の浸潤度 } \\
\hline & $\begin{array}{ll}\text { 浸 潤 } \\
\text { 列 }\end{array}$ & $\mathrm{a}$ & $\mathrm{b}_{1}$ & $\mathrm{~b}_{2}$ & c & $\begin{array}{ll}\text { 浸 潤 } \\
\text { 列 数 }\end{array}$ & $\mathrm{a}$ & $b_{1}$ & $\mathrm{~b}_{2}$ & $\mathrm{c}$ \\
\hline $\mathrm{A}$ & 0 & 0 & 0 & 0 & 0 & 0 & 0 & 0 & 0 & 0 \\
\hline $\mathbf{B}_{1}$ & 4 & 3 & 1 & 0 & 0 & 2 & 2 & 0 & 0 & 0 \\
\hline $\mathrm{B}_{2}$ & 0 & 0 & 0 & 0 & 0 & 0 & 0 & 0 & 0 & 0 \\
\hline $\mathrm{C}$ & 2 & 0 & 0 & 1 & 1 & 0 & 0 & 0 & 0 & 0 \\
\hline $\begin{array}{l}\text { 計 } \\
\%\end{array}$ & 6 & $\begin{array}{c}3 \\
50.0\end{array}$ & $\begin{array}{c}1 \\
16.6\end{array}$ & $\begin{array}{c}1 \\
16.6\end{array}$ & $\begin{array}{c}1 \\
16.0\end{array}$ & 2 & $\begin{array}{c}2 \\
100.0\end{array}$ & 0 & 0 & 0 \\
\hline
\end{tabular}

i 腫瘍部に抬ける浸潤度と周囲の変化との関係（表 17).

まず $1 \mathrm{~cm}$ 部位についてみると，粘膜下浸潤牥浸潤度 $\mathrm{A} て ゙ は$ 認められず， $\mathrm{B}_{1}$ では 5 例中 4 例 $(80.0 \%), \mathrm{B}_{2}$ で 给検索例数がなく, Cでは 2 例中 2 例 $(100.0 \%)$ 飞認 められた。乳頭状増殖は浸潤度 Aで 1 例 (33.3\%), $\mathrm{B}_{1}$ で は 4 例 (80.0\%), Cでは 1 例 $(50.0 \%)$ に認められた。 また陰窩形成は浸潤度 $\mathrm{A} て ゙ 1$ 例 $(33.3 \%), \mathrm{B}_{1}$ では 2 例 (40.0\%), Gでは 1 例 $(50.0 \%)$ を示した. さらに $2 \mathrm{~cm}$ に挄ける変化につてみると, 浸潤度 $\mathrm{A}, \mathrm{B}_{2}$ 及びCで は検索例がなく, $\mathrm{B}_{1}$ で粘膜下浸潤は 4 例中 2 例 $(50.0$ \%)飞認められた。 また乳頭状增殖は認められなかった 分，陰窩形成注 2 例 $(50.0 \%)$ 飞認められた。

ii 腫瘍周囲に抢ける粘膜下浸潤の程度

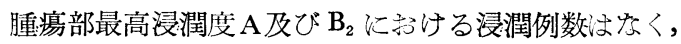
最高浸潤度 $\mathrm{B}_{1}$ に捛りる $1 \mathrm{~cm}$ 部位の浸潤例数は 4 例で あり， 3 例が浸潤度 $\mathrm{a} ， 1$ 例が $\mathrm{b}_{1}$ を示した。 また $2 \mathrm{~cm}$ では 2 例であり， 2 例とも $\mathrm{a}$ を示した。ささらに浸潤度 $\mathrm{C}$ における $1 \mathrm{~cm}$ 部位の浸潤例数惊 2 例であり, 1 例が $\mathrm{b}_{2}$, 1 例がc を示した（表18）.

\section{3 小括}

膀胱部分切除例全体では扁平上皮型が $10.4 \%$, 未分化 細胞型が $4.2 \%$ 示したが，再発例では扁平上皮型 30.0 $\%$, 未分化細胞型 $10.0 \%$ 己移行上皮型江比較し非常に高 率であつた。また浸潤度では48例のうちG牥ずかに 3 例であつたが，再発例の浸潤度をみると，Gが 2 例含ま れている.すなわちCでは 3 例中 2 例俩発を認めたと とになる.さらに腫瘍周囲に招ける組織学的変化では, $1 \mathrm{~cm}$ 部位で 10例中 6 例 $(60.0 \%)$ に粘膜下浸潤を認 わ，また $2 \mathrm{~cm} の$ 部位では 4 例の検索しかなしえなかつ 心ぶ，そのうち2例 (50.0\%) 飞認められた。すなわ 号, 部分切除例全体の成績こ比較してかなり高率である 之考えられる。

\section{第 4 章 総括並びに考按}

膀胱癌化対する膀脱部分切除の予後を左右するもつ之 さ大きな原因として, 切除範囲が挙げられるが, 実際に 臨床的に再発と切除範囲との関係を直接観察しに文献法 比較的少ない。まず Magri によれば，104例の膀胱部分 切除例を切除範囲が 1 inch 以内の症例々それ以上の症 例汇分けて検討しているが, 切除範囲が腫韵辺縁より 1 inch 以内の例の 3 年生存率は $38.1 \%, 1$ inch 以上の例 では63.1\%であると述べている. また教室の鈴木らの報 告では，1.5cm以内とそれ以上に分けて検討している 心゙, 再発率は $1.5 \mathrm{~cm}$ 以内では $73.3 \%, 1.5 \mathrm{~cm}$ 以では 10.0\%であ つたと報告している。市なわち, 明らかに再 発流切除範围によつてかなり異ることが考えられる.

一方この問題を解決しょうとして, 腫瘍周囲の粘膜の 変化を組織学的に検索した報告は比較的多くみられる 汭，いずれもその観察の方法ならびに基準が 異つてい る. まずMasina の報告をみると, 腫瘍周囲粘膜には炎症 性変化とともに腫瘍と同傾向の変化がみられ, この変化 は腫瘍の惡性度と源济 平行するものであること京記載 し, むた Eisenberg et $\mathrm{al}^{9)}$ は53例の乳頭状增殖の腫瘍 周囲粘膜を検索し, Brunn の上皮細胞巣を 7 例に, 乳頭 状增殖を 3 例に, Carcinoma in situ 9 例に認め, さ らに31例の浸潤性腫瘍について同様に検索し, Brunnの 上皮細胞巣を 9 例に, atypical hyperplasia 2 例に, 乳頭状增殖を 1 例に, Carcinoma in situ 9 例に認め たと報告し,また同時にてれら粘膜の増殖性変化の有無 が膀胱腫瘍の予後に対して重大な役割を演じていると述 べている.すなわち Masina 及び Eisenberg et al はい ずれも腫瘍周囲の粘膜における前癌状態や Brunn の上 皮細胞巣，乳頭状増殖などの観察である。ささらに腫瘍よ りはなれた部位の変化について検索した報告をみると， まず Melicow ${ }^{10)}$ によれば腫瘍辺縁 から1〜3 cm離れた 部位に执いては上皮增殖を検索した10例全例に, 䨳胞あ 
るい注腺形成を10例のうち 4 例飞, 扁平上皮化を 2 例 に，上皮細胞巣形成を 2 例に，潰湯形成を 1 例に，さら に早期癌を 2 例に発見したと述べ，また腫瘍膀胱粘膜な 非腫瘍膀胱粘膜に比して上皮の増殖性及び化生性変化つ 頻度ならびに程度が著明に高率であり,さらにこの変化 は腫瘍周囲のみならずその辺縁より 1 ～ $3 \mathrm{~cm}$ 離れた部位 でも同様にみられるととを記載している。 また Simon et $\mathrm{al}^{11)}$ は38例の膀胱全摘除標本を用いて腫湯辺縁から 遠隔部怘での各部について検索し, atypical hyperplasia, Brunn の上皮細胞巣, 榱胞性膀胱炎, Carcinoma in situ などの粘膜変化を約 $89 \%$ に認めるが, これらの変 化は海とんど腫痬縁より 4 〜 $\mathrm{cm} の$ 部位までに認められ たと報告している。

本邦に扮いては, 市川ら ${ }^{12)}$ が腫瑒近接部と遠隔部にわ けて，陰窩状上皮増殖 (Brunnの上皮細胞巣を含む), 囊 胞性膀胱炎, 腺性膀胱炎, 䄉毛性膀胱炎招よび白板症に ついて検索し，陰䆚状上皮増殖は近接部で 40 例中 35 例， 遠隔部で26例中24例に認め，囊胞性膀胱炎を近接部で40 例中 7 例, 遠隔部で 26 例中 3 例飞認め, 腺性膀胱炎を近 接部のみで40例中 2 例に認めている. また䋐毛性膀胱炎 は近接部で 30 例中 2 例, 遠隔部で 26 例中 2 例に, 白板症 は近接部で 40 例中 4 例, 遠隔部で26例中 2 例に認めたこ とを記載している.さらに長谷川 ${ }^{133}$ は21例の上皮性膀胱 腫瘍の全摘除標本を用いて腫瘍の近接部そ遠隔部に扢い 乙乳頭状增殖, 陰窩状増殖, 囊胞形成, 白板症, 粘膜下 炎症, 糜爛などについて検索し, 乳頭状增殖注近接部及 び遠隔部ともに10例 (47.6\%),陰窩状增殖恃近接部で17 例 $(80.9 \%)$, 遠隔部で16例 $(76.1 \%)$, 囊胞形成は近接 部で11例 (52.4\%), 遠隔部で 9 例(42.8\%), 白板症は近 接部及び遠隔部之も亿 2 例 $(9.5 \%)$, 粘膜下炎症は近接 部及び遠隔部とも18例 $(85.7 \%)$, 糜爛は近接部及び遠隔 部とも 3 例 $(14.3 \%)$ 記認めて抢り，膀胱腫瘍では早期 に周囲粘膜の増殖性及び化生性変化をきたすとをを強調

\section{している。}

すなわち，上記つ諸家の成績よりいえることは，腫瘍 周囲の粘膜また洼遠隔部の粘膜に执いてかなりの変化の 認められることがわかるが，これら㳊活とんご粘膜のみ の変化について観察したものであり，また腫痬辺縁より の距離によつていか変化代移り変るかについては検索 を行つていない，し岕がつて，上述の報告をもとにして 部分切除術の切除範囲を決定することは困難である.よ つて私は, 部分切除術の切除範围の決定を組織学的に及 るために，腫瘍辺縁より $1 \mathrm{~cm}, 2 \mathrm{~cm}, 3 \mathrm{~cm}$ と離れた部位
で全層標本を作成し, 粘膜下への浸潤状態の観察に重点 を置き, さらに乳頭状增殖, 陰窩形成についても観察を 行つた。 また同時に, 部分切除標本では術後再発例之非 再発例について比較検討を行つた。

末ず腫瘍周囲の粘膜下浸潤について考察してみる々， この変化は粘膜の及つ変化とは異 ), 癌の浸潤性発学を 示すものと考えられ, 膀胱部分切除標本の辺縁でこの听 見を認めることは術後再発をまぬがれえないものと考元 られ，末た同時に切除範围を決定するのに，もつ上も関 係のある因子と考えら㣗る。し玑しの点関方る報告 はまつたく認められザ，私の成績についてみると，志ず 部分切除標本では $1 \mathrm{~cm}$ 部で粘膜下浸潤を $43.7 \%, 2 \mathrm{~cm}$ の部で18.7\%に認められた。また再発例でみると， $2 \mathrm{~cm}$ まで検索できたの惊 4 例であるが，てのうち 2 例牥 $2 \mathrm{~cm}$ の部位に粘膜下浸潤心認められている。 さらに全摘除例 につてみると，1 cmの部位で $68.0 \%, 2 \mathrm{~cm}$ の部位で、 $52.0 \% ， 3 \mathrm{~cm}$ 部位では27.3\%に認められた。 いずれて しても粘膜下浸潤がかなり高率に認められることがわ氻 る.すなわち, 部分切除例と全摘除例との間では明ら亦 に差が認められ，ま心同時に, 腫瘍辺縁よりの距離が離 れるにしたがつて少なくなることがわかる。

つぎに, 粘膜の増殖性変化である乳頭状増殖について 考察してみると, この変化は増殖変化であつて, かなら ずしもすべてが癌に移行するものとは考えられないが， Melicow によればこの変化は発癌因子により乳頭腫上 なり，さらに乳頭状癌あるいは無德性癌に移行するこ上 が考えられると述べている. また長谷川, Eisenberg et al 及び Austen-Friedel1 ${ }^{14)}$ らは組織学的に検索した結 果, しの様な粘膜つ増殖性変化の有無は膀胱腫湯つ予後 に対して重大な役割を演じていると述べている，军なう ち腫瘍周囲の粘膜の変化としては重要な要素であるこ考 えられる。 その成績:ついてみると, Eisenberg et al によれば84例中 4 例汇認められたにすぎないと述べてい るが，長谷川は近接部及び遠隔部で夫ふ $47.6 \%$ と高率し 認められる己報告している．私の成績についてみる己， 部分切除例では $1 \mathrm{~cm}$ 部位で $50.0 \%$ K， $2 \mathrm{~cm}$ 部位で: 18.7\%に認められている。.また全摘除例では $1 \mathrm{~cm}$ 部位

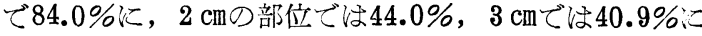
認められた。すなわ方乳頭状增殖は粘膜下浸潤と同様汇 全摘除例に打いて高頻度に認められ，また同時に，腫瘍 縁よりの距離が離れるとともにその頻度は減少すること がわかる。

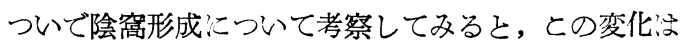


Bothe $^{15)}$, Fagerstrom ${ }^{16)}$ らによると, 正常の腎孟, 尿管, 膀胱の粘膜にしばしば認められる所見であり，年令とと もに増加する傾向があると述べ，さらに Bothe は陰窩 形成よりの発癌の可能性を述べている。 また長谷川は上 皮性膀胱腫瘍では21例中17例飞認めたが, 非腫瘍性膀胱 では 24 例中 4 例に認めたにすぎず，との間には相当の差 があると述べている。ささら Nesbit ${ }^{17)}$ は尿中のある種 の発癌性物質により陰窩形成が発生し, これが組織学的 に Carcinoma in situ を伴うことがあるととを強調し ている.したがつて多くの研究者もこの変化を重視して 検索しているが, Eisenberg et al は腫瘍周辺の粘膜で 粎19\%に, Melicowも20\%に認められると述べている. しかし市川らは近接部で $88 \%$, 遠隔部では $92 \%$, 長谷 川も近接部で $80.9 \%$, 遠隔部で76.1\%に認められると述 べている. 私の成績についてみると, 部分切除例では 1 cmの部位で45.8\%，2 cmでは34.4\%に認められている. すなわち, 市川ら, 長谷川らの成績ではきわめて頻度が 多く，また近接部と遠隔部とで后とんで差のない成績で あると述べているが，私の成績では $1 \mathrm{~cm} ， 2 \mathrm{~cm}$ とも50\% 以下であり,また粘膜下浸潤や乳頭状增殖海ど大きな差 没認められなかつたが，市川ら，長谷川の成績と異な り, $2 \mathrm{~cm}$ の部位ではややり多少少ない数を示した. しか 乙全摘除例に执いてね， $1 \mathrm{~cm}$ 部位で $40.0 \%, 2 \mathrm{~cm}$ $48.0 \%, 3 \mathrm{~cm} て ゙ 36.4 \%$ 亿認められ, やはりその頻度は部 分切除標本の場合之同様であるが, $1 \mathrm{~cm}, 2 \mathrm{~cm}, 3 \mathrm{~cm}$ 間では拣とんど差の認められない成績を示した。

すなわち, 以上のでとく考察を加えてみると, 明らか に肉眼的に異常がないと思われる腫瘍周囲の粘膜ならび 飞粘膜下組織に腫瘍浸潤ならびに癌前躯症としての変化 が存在するととがわかるが, この成績より部分切除を行 う際に重要な切除範囲の問題を考えてみると, まず粘膜 下浸潣についてみると, 明らかに $2 \mathrm{~cm}$ 部位ではその発 生頻度が少なくなるととがわかり,ついで乳頭状増殖で む $1 \mathrm{~cm}$ 部位では非常に高率に認められているが， 2 $\mathrm{cm}, 3 \mathrm{~cm}$ でややり $1 \mathrm{~cm}$ 部位よりは頻度が少なくなつ ている。また陰䆚形成についてるると, 全摘除標本では $1 \mathrm{~cm}, 2 \mathrm{~cm}, 3 \mathrm{~cm}$ あ゙り差が認められなかつたが, 部 分切除標本ではやはり $2 \mathrm{~cm}$ 部位で少ない数を示した. すなわち，いずれの変化も $2 \mathrm{~cm}$ 部位になると少ないこ とがわかるが，とくに再発に直接関係あると考えられる 粘膜下浸潤の成績を重視して考えると, 切除範囲は $2 \mathrm{~cm}$ までは必ず行う必要のあることが強調される。一方との 事実をすでに述べた臨床成績と比較検討してみると，
Magri は切除範囲が腫瘍辺縁より 1 inch 以内のもの亡, 1 inch 以上の例に打ける 3 年生存率を検討している

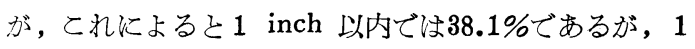
inch 以上の例では63.1\%であると述べ，鈴木らは切除 籁囲が $1.5 \mathrm{~cm}$ 以内の症例 上 $1.5 \mathrm{~cm}$ 以上の症例 とにわけ て, その再発率を検討しているが，乙れによると切除範 囲が $1.5 \mathrm{~cm}$ 以内では $73.3 \%$ 亿再発が認められるが, $1.5 \mathrm{~cm}$ 以上ではわずかに $10.0 \%$ 亿すぎないとを強調し, 切除 以腫湯辺縁より $1.5 \mathrm{~cm}$ 以上離れて行了必要のあるととを 報告している. すなわち, 私の病理組織学的検索上り恕 た切除範囲は, 明らかにこ秃らの成績を裹付けるもの上 考えられる. また同時に, 私の成績にもとづいた切除を 臨床例に刘して行えば, 部分切除術によつてもかなりの 根治性が期得されるものと思われる.

つぎに浸潤度と周囲粘膜の変化との関係について考六 てみると, Masina ${ }^{18}$ によれ没粘膜の変化と腫瘍の惡性 度との関係は添とんで一致し, 惡性度が上昇するととす 亿粘膜の変化は高度となると述べているが, 長谷川は腫 瘍の惡性度とは平行関係がないと述べ, Simon et al, Austen-Friedell らむ惡性情及び浸潤度との間に相関々 係がないる記載している。しかし私の成績についてみる と, まず部分切除例では $1 \mathrm{~cm}$ 部に执いて, 粘膜下浸潤 注浸潤度Aに执いて $25.0 \%$ あるが，浸潤度 $\mathrm{B}_{1}$ 以上の 例では61.1〜66.6\% と割合高率に認められるょうにな り， $2 \mathrm{~cm}$ 亿拉いても浸潤度 $\mathrm{B}_{1}$ ご41.6\%に認められてい る. また全摘除例の成績でもや牥り同様で, $1 \mathrm{~cm}, 2 \mathrm{~cm}$ の部位とも $\mathrm{B}_{1}$ 以上になるとAよりは高率江認められる ようになる。しかし乳頭状増殖及び陰窩形成は浸潤度之 の間に相関々係は認められず, 長谷川, Simon et al, Austen-Friedell らの報告と一致している.すなわち, 粘 膜下浸潤のみは腫瘍部の浸潤度と平行して頻度が高くな ることがわかるが, このこ之次重大であり, 膀胱部分切 除術を行うにあたつては, や怡り発生腫瘍の浸潤度の判 定を正確に把握することが必要である。ま何時に浸潤 度が高度になると, 再発の多い事実は腫瘍周囲つ粘膜下 浸潤によつて左右されることも考えられる。

つ私は, 腫瘍辺縁より $1 \mathrm{~cm}, 2 \mathrm{~cm}, 3 \mathrm{~cm}$ 部位の 粘膜下浸潤の深部への浸潤状態を検索した.すなわちこ のような検索を行つた報告はい季だ認められないが, 私 の成績を述べると，まず部分切除例についてみると， 1 cmの部位に抬ける粘膜下浸潤のうち $\mathrm{a}$ 注 $71.4 \%$, 筋層半 谈までの浸潤を示す $b_{1}$ は23.8\%, 筋層外までの浸潤を

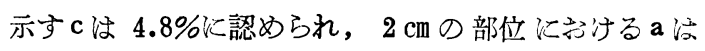


66.7\%, $\mathrm{b}_{1}$ 汸33.3\%記認められている．またての変化を 腫瘍部の浸潤度と比較検討してみると， $1,2 \mathrm{~cm}$ ともに $B_{1}$ 以上の変化济いが记も腫瘍部の浸潤度が $B_{1}$ 以上の例 に把いて諗めら㣗，とくに low stage に属する浸潤度 $\mathrm{B}_{1}$ に掠いても $1 \mathrm{~cm} の$ 部位ご11例中 4 例, $2 \mathrm{~cm}$ 部位で

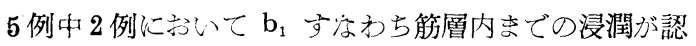

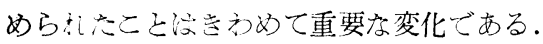

また一方, 全摘除例心゙洁 $1 \mathrm{~cm}$ の部位で a を示すものは $70.7 \%, b_{1}$ は23.5\%，c 法 5.8\%記認められ， $2 \mathrm{~cm}$ 部位で、 $\mathrm{a}$ 洨 $92.3 \%, \mathrm{c}$ 统 $7.7 \%$ あり, $3 \mathrm{~cm}$ 部位で

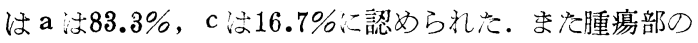
浸潤度との関係をみると，乙の場合は $\mathrm{b}_{1}$ 以上の変化は 1，2，3 cm とも汇腫瘍部の浸潤度が $\mathrm{C}$ 例に执いて認 めら方さ。すなわち，以上の結果をもとにして考える と, 睡瘍周囲汇招汀る浸潤䧔, かなりの頻度で意外に深 部にまご達していることがわかり, 発生腫場の浸潤状態 を腫瘍部汇括いての及検索したのでは実際の腫瘍の掋が り在判定しなといえないものと考えら礼る. 云い換える と, 腫瘍部の浸潤上周囲入の拡がりを同時に検索しなけ れば真つ腫瘍の進展状態を把握ごきないととが強調され

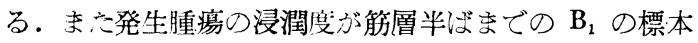
でも $1 、 2 \mathrm{~cm}$ 粘膜下浸潤方腫湯部同様に筇層にまで達 している事実より考えると，部分切除を行うにあたつて は, 腫瘍部の浸潤度に一関係なく, $2 \mathrm{~cm}$ 以上の充分な切除 の必要性がさらに強調さ礼る。

\section{第 5 章 結 語}

東北大学泌尿器科学教室において経験した膀胼腫渮の 亏与, 竍胱部分切除術によつてえられた48例の標本なら びに全摘除術によつてえられた25例の標本を用いて, 膀 胱部分切除術の切除範囲の決定圭行了目的で，種々なる 病理組織学的な検討を行い，つぎの結果をえた。

1 細胞型冲部分切除例及び全摘除例ともに移行上皮 型が $80 \%$ 以上を占め, ついで扁平上皮型, 未分化細胞型 の順ざあつ㐫。しかし部分切除例で 1例 ( $2.1 \%)$ 飞腺 状細胞型が認められ沈。

案太浸潤度で淰，Oのものは認められず, 部分切除例 では Aが50.0\%， $\mathrm{B}_{1}$ が $29.2 \%, \mathrm{~B}_{2}$ が12.5\%，Cが 8.3

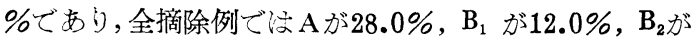
$24.0 \%, \mathrm{Cが} 36.0 \%$ を示した.

再発例で洨，移行上皮型が $60.0 \%$, 扁平上皮型が 30.0 $\%$ ，未分化細胞型が $10.0 \%$ 示し，浸潤度は Aが 30.0 $\%, B_{1} か ゙ 50.0 \% ， \mathrm{Cが} 20.0 \%$ 示した。

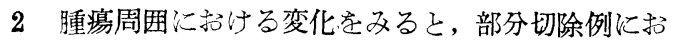

いて, 粘膜下浸㵎ま $1 \mathrm{~cm}$ 部位で $43.7 \%, 2 \mathrm{~cm}$ 部位で 18.7\%沉認められ，乳頭状增殖は $1 \mathrm{~cm} て ゙ 50.0 \% ， 2 \mathrm{~cm} て ゙$ は $18.7 \%$ 示し, $1 \mathrm{~cm}$ と $2 \mathrm{~cm}$ 間では著明な差が認めら れた。しかし陰䆚形成は $1 \mathrm{~cm}$ 示し, $1 \mathrm{~cm}, 2 \mathrm{~cm}$ との間に抬ける著明な差は認められな かつた. また全摘除例に执いても同様に検索したが, 粘 膜下浸潤は $1 \mathrm{~cm}$ 部位で $68.0 \%, 2 \mathrm{~cm}$ の部位で $52.0 \%$, $3 \mathrm{~cm}$ 部位で $27.3 \%$, 乳頭状堌殖も $1 \mathrm{~cm} て ゙ 84.0 \%, 2$ $\mathrm{cm} て ゙ 44.0 \%, 3 \mathrm{~cm}$ で $40.9 \%$ を示し, 部分切除標本同様に 腫瘍辺縁より距離が離れるとともに減少する倾向が認め られた。しかし陰窩形成は部分切除標本同樣に距離によ る差が認められなかつた。すなわち, 以上の結果より術 後の再発に直接関係のある粘膜下浸潤及び乳頭状增殖を もとにして考えると, 部分切除術を行うにあたつては腫 瘍辺縁より $2 \mathrm{~cm}$ 以上離れた部位まで切除する必要のある ことが強調される。

3 腫瘍部の浸潤度と腫瘍周囲法打りる変化との関係 についてみると, 部分切除例に打ける $1 \mathrm{~cm}$ 部位の粘膜 下浸潤は腫痬部浸潤度 $\mathrm{A}$ に扔いて $25.0 \% ， \mathrm{~B}_{1}$ 以上では 61.1 66.6\% と高率涩認められ， $2 \mathrm{~cm}$ 部位でも浸潤度 $\mathrm{B}_{1} て ゙ 41.6 \%$ 認められている. また全摘除例でも $1 \mathrm{~cm}$. 部位に打りる粘膜下浸潤は浸潤が $\mathrm{B}_{1}, \mathrm{~B}_{2}, \mathrm{C}$ となると ともにそれぞれ66.0，83.3，77.3\%と高率に認められる

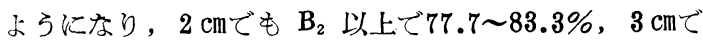
も $\mathrm{B}_{2}$ 以上で25.0〜 50.0\%を示した. しかし乳頭状增殖 及び陰䆚形成は浸潤度の間に相関々係は認められなかつ た.すなわち, 粘膜下浸潤だけはは湆腫瘍部浸潤度と平 行しているととがわかり, 発生腫瘍の浸潤度を術前に把 握することは重要であり, 浸潤度が高度な場合はさらに 切除の範囲を考慮する必要のあるととがいえる。

4 腫瘍周囲に打ける粘膜下浸潤の程度について検荣 したが, 部分切除例では $1 \mathrm{~cm}$ 部位で a を示すものは $71.4 \%, b_{1}$ は23.8\%, c は 4.8\%に認められ， $2 \mathrm{~cm}$ 部 位で $\mathrm{a}$ を示すものは $66.7 \%, \mathrm{~b}_{1}$ は $33.3 \%$ ，末た全摘除 例において $1 \mathrm{~cm}$ 部位で a を示したものが70.7\%, $\mathrm{b}_{1}$ を 示したものが $23.5 \%$, c を示したものが $5.8 \%$ に認めら

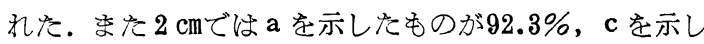

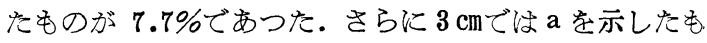
のが $83.3 \% ， \mathrm{c}$ を示したものが $16.7 \%$ 示した。

すなわち, 畽㴼周囲における粘膜下浸潤はかなり高頻 度で深部にまで達しているととがわかるが，とくに浸潤 の浅い $B_{1}$ でも, $1 \mathrm{~cm}$ 部位で $36 \%$ に, $2 \mathrm{~cm}$ 部位で40 \%に発生腫瘍と同程度の浸潤を認めたととは重要なとと 
で，膀胱腫瘍々早期より浸潤え゙周团に波及しているとと が考えられ，腫瘍の浸潤度に心かわらず，やはり腫瘍辺 縁より $2 \mathrm{~cm}$ 以上の切除の必要性が考えられる.

稿を終るに臨み，終始御愍篤な御指導と御校閲を賜つ た恩師宾戸仙太郎教授に深甚なる謝意を表します。また 貴重なる御助言，御協力を载いた鈴木騏一，杉田篤生両 講師に感謝します。

な和本論文の要旨は, 第13回東北癌集談会及び第53回 日本泌尿器科学総会に拈いて発表した。

本研究の費用の一部は文部省科学試験研究費によっ た。っつしんで謝意を表します。

\section{文献}

1) Gammelgaard, P.A. \& Morville, P.: Acta. chir. Scandinav., 105, 96, 1953.

2) Masina, F.: Brit. J. Surg., 41, 494, 1954.

3) Nichols, J.A. \&Marshall, V.F.: Cancer., 9, $559,1956$.

4）楠隆光：日泌尿会誌，49，591,1958.
5）鈴木㬴一, 杉田篤生, 三浦忠雄, 加藤正和, 小 野寺䇺, 矢吹日出雄, 加藤輝彥: 日泌尿会誌, $57,380,1966$.

6) Magri, J.: Brit. J. Urol., 34, 74, 1962.

7) Baker, R.: J. Urol., 73, 681, 1955

8) Jewett, H.J. \& Strong, G.H.: J. Urol., 55, $366,1946$.

9) Eisenberg, R.B., Roth, R.B.\& Schweinsberg, M.H.: J. Urol., 84, 544, 1960.

10) Melicow, M.M.: J. Urol., 68, 261, 1952.

11) Simon, W., Cordonnier, J.J. \& Snodgrass, W.T.: J. Urol., 88, 797,1962.

12）市川第二, 辻一郎, 石井澄子 : 日泌尿会誌, 43, $19,1952$.

13）長谷川泰：日泌尿会誌, 46 .296, 1955.

14) Austen, G.Jr. \& Friedell, G.H.: J. Urol., 93, 224, 1965.

15) Bothe, A.E.: J. Urol., 53, 451, 1945.

16) Fagerstrom, D.P.: J. Urol., 59, 333, 1948.

17) Nesbit, R.M.: J. Urol., 75, 443, 1956.

18) Masina, F.: Brit. J. Urol., 24, 344, 1952.

（昭和 41 年 1 月 20 日受付） 